\title{
Çalışma Yaşamında X ve Y Kuşağının Motivasyonunu Etkileyen Faktörler Üzerine Nitel Bir Araştırma (A Qualitative Research on Factors Affecting the Motivation of Generations $\mathrm{X}$ and $\mathrm{Y}$ in Business Life)
}

\section{Ebru YILDIZ iD a}

a Beykent Üniversitesi, İktisadi ve İdari Bilimler Fakültesi, İstanbul, Türkiye. ebruyildiz@beykent.edu.tr

\begin{tabular}{|c|c|}
\hline MAKALE BİLGİSİ & ÖZET \\
\hline $\begin{array}{l}\text { Anahtar Kelimeler: } \\
\text { Kuşak }\end{array}$ & $\begin{array}{l}\text { Amaç - Bu çalışmanın amacı, X ve Y Kuşağının çalışma yaşamında motivasyonunu etkileyen faktörleri } \\
\text { ortaya koymaktır. }\end{array}$ \\
\hline $\begin{array}{l}\text { Motivasyon } \\
\text { X Kuşağı } \\
\text { Y Kuşağ1 }\end{array}$ & $\begin{array}{l}\text { Yöntem - Çalışma, nitel araştırma desenlerinden biri olan olgubilim (fenomenoloji) deseninde } \\
\text { yürütülmüştür. Katılımcıların belirlenmesinde amaçlı örnekleme yöntemlerinden maksimum çeşitlilik } \\
\text { örneklemesi kullanılmıştır. Bu amaçla, eğitim düzeyi, sektör, görev, çalışma süresi bakımından çeşitlilik } \\
\text { gösteren X Kuşağ1 temsilcisi } 15 \text { ve Y Kuşağ1 temsilcisi } 15 \text { kişi olmak üzere toplam } 30 \text { çalışan araştırma }\end{array}$ \\
\hline $\begin{array}{l}\text { Gönderilme Tarihi } 1 \text { Eylül } \\
2020\end{array}$ & $\begin{array}{l}\text { örneklemini oluşturmaktadır. Araştırmada veri toplamak üzere görüşme yöntemi kullanılmıştır. Veriler, } \\
\text { içerik analizi yöntemi ile analiz edilmiştir. }\end{array}$ \\
\hline $\begin{array}{l}\text { Revizyon Tarihi } 27 \text { Aralık } \\
2020 \\
\text { Kabul Tarihi } 7 \text { Mart } 2021\end{array}$ & $\begin{array}{l}\text { Bulgular - Araştırma, X ve Y Kuşağının motivasyonunu etkileyen pek çok husus ortaya koymakla beraber, } \\
\text { ekonomik faktörler ile birlikte çalışma ortamının anlayış, uyum, cana yakınlık, hoşgörü, saygı gibi } \\
\text { psikolojik yönlerinin X Kuşağı çalışanların motivasyonunda öncelikli faktörler olduğunu göstermektedir. } \\
\text { Y Kuşağı çalışanlar ise ekonomik araçlar ve kariyer gelişimi ile birlikte kendilerini değerli hissettikleri, } \\
\text { samimi, esnek ve rahat bir çalışma ortamını motivasyonda öncelikli hususlar olarak belirtmiştir. } \\
\text { Çalışmada, X ve Y Kuşağının motivasyonunda benzerliklere de vurgu yapılmıştır. }\end{array}$ \\
\hline $\begin{array}{l}\text { Makale Kategorisi: } \\
\text { Araştırma Makalesi }\end{array}$ & $\begin{array}{l}\text { Tartışma - Çalışma, X ve Y Kuşağının iş yaşamındaki ihtiyaç, istek ve beklentilerinin daha iyi anlaşılması } \\
\text { ve motivasyonu açısından ortaya koyduğu önemli sonuçlar ile çok kuşaklı bir çalışma ortamının daha iyi } \\
\text { yönetilmesinde literatüre ve uygulamacılara katkı sunmaktadır. Bu bağlamda, örgütlerin arzu edilen bir } \\
\text { çalışma ortamı oluşturmalarında bu sonuçlardan faydalanmaları büyük önem taşımakta; araştırmacıların } \\
\text { ise bu kuşakların çalışma dinamiklerini anlamaya ilişkin daha fazla araştırma ortaya koymaları } \\
\text { gerekmektedir. }\end{array}$ \\
\hline
\end{tabular}

\begin{tabular}{|c|c|}
\hline ARTICLE INFO & ABSTRACT \\
\hline $\begin{array}{l}\text { Keywords: } \\
\text { Generation } \\
\text { Motivation } \\
\text { Generation X } \\
\text { Generation Y } \\
\text { Received } 1 \text { September } \\
2020 \\
\text { Revised } 27 \text { December } \\
2020 \\
\text { Accepted } 7 \text { March } 2021\end{array}$ & $\begin{array}{l}\text { Purpose - This study aimed to reveal the factors affecting the motivation of Generations } X \text { and } Y \text { in } \\
\text { business life. } \\
\text { Design/methodology/approach - The study was conducted in the phenomenology design, one of the } \\
\text { qualitative research designs. Maximum diversity sampling, one of the purposeful sampling methods, was } \\
\text { used in determining the participants. To this end, a total of } 30 \text { employees, including } 15 \text { individuals from } \\
\text { Generation } X \text { and } 15 \text { individuals from Generation } Y \text { who varied in terms of the level of education, sector, } \\
\text { duty and working time, constituted the sample of the study. The interview method was used to collect the } \\
\text { data in the study. The data were analyzed by the content analysis method. } \\
\text { Results - While the study revealed many issues affecting the motivation of Generations } X \text { and } Y \text {, it also } \\
\text { showed that the psychological aspects of the work environment, such as understanding, harmony, } \\
\text { friendliness, tolerance and respect, along with economic factors were primary factors in the motivation of } \\
\text { employees of Generation X. The employees of Generation } Y \text { indicated that a friendly, flexible and } \\
\text { comfortable work environment, where they felt valuable, along with economic tools and career } \\
\text { development, were the primary issues in motivation. The similarities in the motivation of Generations } X \\
\text { and } Y \text { were also emphasized in the study. } \\
\text { Discussion - With the important results revealed by this study for a better understanding of the needs, } \\
\text { wishes, and expectations of Generations } X \text { and } Y \text { in business life and their motivation, it contributes to the } \\
\text { literature and practitioners with regard to better management of a multi-generational work environment. } \\
\text { In this context, it is of great importance for organizations to use these results in creating the desired work } \\
\text { environment, and researchers should conduct more studies on understanding the working dynamics of } \\
\text { these generations. }\end{array}$ \\
\hline
\end{tabular}




\section{Giriş}

Günümüz iş dünyası, özellikle bilgi ve iletişim teknolojilerinin hızla gelişmesi, artan küreselleşme ve rekabet ile birlikte önemli değişiklikler yaşamaktadır. Örgütsel faaliyetlerin şeklinin ve konumunun değiştiği bu yeni çalışma düzeni, örgütlere fırsatlar sunduğu gibi, zorluklara da neden olmaktadır. Rakiplerine kıyasla daha esnek, hızlı ve çevik olmak zorunda olan örgütlerin bu hareket kabiliyeti, insan kaynağına dayanmaktadır. Örgütler için büyük bir rekabet avantajı kaynağı olan çalışanlar, yönetilemediğinde büyük bir zorluk haline de gelebilmektedir. Benzer doğum yılları ve özellikle tarihsel ve sosyokültürel bağlam dolayısıyla ortak deneyimler ile değer, inanç, beklenti, tutum ve davranış benzerliğine sahip kişilerin oluşturduğu topluluk şeklinde ifade edilebilen kuşaklar, önceki dönemler ile kıyaslandığında, örgütlerde daha çok bir arada çalışarak "çok kuşaklı bir çalışma ortamı" yaratmakta; bu yüzden bu kuşak çalışanların ihtiyaç, istek ve beklentilerini anlayarak onları mutlu ve motivasyonu yüksek bireyler olarak örgütsel amaçlara yönlendirmek daha da önem kazanmaktadır. Bireyin bireysel ve örgütsel yaşamında hedeflerini gerçekleştirebilmek için ne kadar çok çaba gösterdiğini, bu çabanın ulaşılmak istenen hedefler doğrultusunda olup olmadığını ve ne kadar süre ile devam ettiğini ifade eden motivasyon kavramı, son derece karmaşık bir doğaya sahip olduğu gibi, bu karmaşıklık çok kuşaklı bir işgücü ile birleştiğinde, farklı kuşakların çalışma yaşamındaki motivasyon kaynaklarının anlaşılması, dikkate değer bir konu haline gelmektedir.

Bu bağlamda, literatürdeki yaygın sınıflandırmada X Kuşağı (1965-1979) ve Y Kuşağı (1980-1999) şeklinde adlandırılan, ülkemiz nüfusu ve işgücündeki yeri ile dikkat çeken bu kuşakların motivasyonunu etkileyen faktörleri tespit etme amacını taşıyan bu çalışma, kuşaklar ve motivasyon ilişkisinin daha fazla çalışma ile incelenmesi gereken özellikle yerli literatüre katkı sağladığı gibi, örgütlere de yol gösterici niteliğinde sonuçlar ortaya koymaktadır.

Araştırma, nitel araştırma desenlerinden olgubilim (fenomenoloji) deseninde yürütülmüştür. Amaçlı örnekleme yöntemlerinden maksimum çeşitlilik örneklemesi ile araştırmanın örneklemi belirlenmiştir. Eğitim düzeyi, sektör, görev ve çalışma süresi itibariyle çeşitlilik gösteren $X$ Kuşağından 15 ve Y Kuşağından 15 olmak üzere toplam 30 çalışan, araştırmanın örneklemini oluşturmaktadır. Veriler, görüşme yöntemi ile Ocak-Şubat 2019 tarihlerinde toplanmış olup, içerik analizi yöntemi ile analiz edilmiştir.

Çalışmada, öncelikle kuşak kavramı ile $X$ ve $Y$ Kuşağına ilişkin ayrıntılı açıklamalara yer verilmiştir. Sonrasında, motivasyon kavramı ele alınmış; devamında yerli ve yabancı literatürde yer alan araştırma bulguları ile bu kuşakların çalı̧̧ma yaşamında motivasyonunu etkileyen faktörler sunulmuştur. Sırasıyla diğer bölümlerde araştırma metodolojisi ayrıntıları ile anlatılmış ve bulgular ortaya konmuştur. Araştırmanın sonuç bölümünde, elde edilen bulgular literatürdeki diğer çalışmalar ile karşılaştırmalara da yer vererek yorumlanmış; uygulamacılara ve araştırmacılara önerilerde bulunulmuştur.

\section{Kavramsal Çerçeve}

\subsection{Kuşak Kavramı}

Kuşak kavramı, sosyoloji, psikoloji, ekonomi, siyaset gibi pek çok disiplinin konusu olmakla birlikte, son yıllarda özellikle yönetim disiplininde üzerinde giderek artan araştırma sayısı ile önemli bir konu haline gelmiştir. Kuşak kavramının tanımı, disiplinler arasında farklılık göstermektedir. Ancak yaygın görüşe göre kuşak, "kritik gelişim evrelerinde doğum yıllarını paylaşan, aynı tarihsel ve sosyokültürel bağlamda doğmuş, bir dizi ortak yaşam olayları deneyimlemiş, aynı değerleri, inançları, beklentileri, tutumları ve davranışları paylaşan bir grup insan veya topluluk" şeklinde tanımlanmaktadır (Eriş vd., 2013: 152; Yusoff ve Kian, 2013: 98; Fatimah vd., 2015: 22; Kicheva, 2017: 104). Mannheim (2018: 331-332), aynı kuşağa ya da yaş grubuna ait olma olgusunun, ortak olan bireyleri hem toplumsal ve tarihsel süreçte ortak bir yerleşimle donattığını hem de kendine özgü belirli bir düşünce ve deneyim tarzına, tarihsel olarak uygun bir eylem kalıbına önceden yatkın kılmak suretiyle onları mümkün deneyimin özel bir menziliyle sınırladığını belirtmektedir. Araştırmacılara göre, bir kuşağı karakterize eden doğum yılları ve o zamanki olaylar olmak üzere iki ana faktör bulunmaktadır (Kicheva, 2017: 104). Ancak, doğum yılları kuşaklar arasında ayrım yaparken göz önünde bulundurulan nispeten küçük bir faktördür. Bunun yerine, çoğu araştırmacı kuşakların kronolojik tarihlerden çok "tarih"e göre şekillendiğini savunmaktadır (Jiří, 2016: 108). Kuşakların yaşamını etkilemiş önemli tarihsel, politik, sosyoekonomik ve kültürel olaylar, kuşaklara ait özellikleri şekillendiren hususlar olduğu gibi, aynı zamanda kuşaklar arasındaki farkların da belirleyicilerindendir (Süral Özer, 2016: 358; Jiří, 
2016: 110). Bu yüzden, her kuşağın kendine özgü deneyimleri, beklentileri, alışkanlıkları, tutumları, davranışları ve motivasyon vasıtaları, nitekim kendine özgü bir benzersizliği vardır (Yusoff ve Kian, 2013: 98; Fatimah vd., 2015: 22; Kicheva, 2017: 103).

Literatürde kuşakları sınıflandırmak için standart bir terminolojinin olmadığı görülmektedir. Kuşakları tanımlamak için kullanılan isimler ve kuşakların yaş sınırları üzerine bir görüş birliğinin olmadığını, bu hususların yapılan çalışmalarda araştırmacıların referans aldıkları kaynaklara göre şekillendiğini söylemek mümkündür. Eriş vd. (2013: 152), kuşakların nasıl belirlendiğinin dünya genelinde farklılık gösterdiğini, örneğin, İsrail'de kuşakların savaşlarla, ABD'de ise genellikle doğum oranlarına ve büyük olaylara dayalı olarak tanımlandığını belirtmektedir. Bir kuşağın süresi hakkında da oldukça değişik değerlendirmeler vardır. Çoğu araştırmacı bu süreyi on beş yıl olarak belirlerken, kimileri kuşak kelimesiyle otuz yılı kastetmektedir (Mannheim, 2018: 316). Diğer yandan, araştırmacılar teknoloji kullanımı, iletişim, vb. alanlarda değişimin hızı arttıkça, kuşakların potansiyel olarak kısaldığını ve kuşaklar arasındaki farkların keskinleştiğini vurgulamaktadır (Jiří, 2016: 120; Kicheva, 2017: 103).

Bu bilgiler ışı̆̆ında literatürde yaygın sınıflandırma, Sessiz Kuşak (1925-1944), Bebek Patlaması Kuşağı (19451964), X Kuşağı (1965-1979), Y Kuşağı (1980-1999) ve Z Kuşağı (2000-2018) olmak üzere beş ayrı kuşak ortaya koymaktadır. "Gelenekçiler (Traditionalists)", "Erişkinler (Matures)", "Gaziler (Veterans)" olarak da adlandırılan Sessiz Kuşak (Jiř́i, 2016: 107-108), iki dünya savaşı arasında doğmuş, dünya ekonomik bunalımına tanık olmuş, 20. yüzyıl başlangıcının en genç ve Türkiye'de Cumhuriyet Dönemi'nin ilk kuşağıdır (Kuran, 2019a: 41). Otoriteye saygı, disiplin, sadakat ve fedakarlık, bu kuşağın en temel değerleri arasında yer almaktadır (Zemke vd., 2000: 2; Jiř́, 2016: 108-109). "Savaş Sonrası Kuşak" (Kicheva, 2017: 106), "Sandviç Kuşak" (Kuran, 2019a: 60) şeklinde adlandırılan Bebek Patlaması Kuşağının temel değerleri iyimserlik ve katılımdır (Jiří, 2016: 108). Rekabetçi, çalışkan, sadık, eylem odaklı, sabırsız ve "çalış ve sonra öl" anlayışını benimseyen bu kuşak için iş her şeyden önemlidir (Kicheva, 2017: 110). X Kuşağına, "MTV Kuşağı", "Me (Ben) Kuşağı", "Boynunda Anahtar Olan Çocuklar", "13. Kuşak" ve Türkiye'de "Özal Kuşağı" gibi çeşitli isimler verildiği görülmektedir (Kuran, 2019a: 82). Kendine güvenen, kendine yeten, küresel düşünen, özgürlüğe ve sorumluluğa değer veren, bağımsız, görev yönelimli, şüpheci ve genellikle sabırsız X Kuşağı (Jiř́i, 2016: 108109; Kicheva, 2017: 110-111), iş-yaşam dengesine önem vermekte; "ilk sırada yaşam, ikinci sırada iş" anlayışını benimsemektedir (Kicheva, 2017: 110). "Milenyum Kuşağı" (Ng vd., 2010: 281-292; Gross, 2017: 10), "Sonrakiler (Nexters)" (Zemke vd., 2000: 1-8) gibi pek çok isimle anılan ve kendine güven, sosyallik, çoklu görev yapma, eğitim odaklı olma, esnekliğe ihtiyaç duyma, eğlence arama ve sabırsızlık özelliklerine sahip Y Kuşağı, "yaşam tarzının bir parçası olarak iş" anlayışını benimsemektedir (Kicheva, 2017: 110). "Dijital Yerliler", "Yeni Sessiz Kuşak" olarak da adlandırılan Z Kuşağı (Jiř́, 2016: 109), bugüne kadarki en teknoloji meraklısı kuşak olup, kendilerini nüfuzlu, girişimcilik zihniyetine sahip, düşünceli, sadık, şefkatli, açık fikirli, sorumlu, sosyal konulara duyarlı, biz merkezli bireyler olarak tanımlamaktadırlar (Loveland, 2017: 36). Bilgi teknolojisi ve sosyal medya becerilerinin, bu kuşağın çalışma yaşamına getireceği en güçlü özellikler olduğu düşünülmektedir (Deloitte, 2017: 30).

Yukarıda kuşakların sınıflandırılması ve özelliklerine ilişkin yapılan değerlendirme, şüphesiz önemli bir perspektif sunmakla birlikte, araştırmacılar belirli bir yılda doğmuş bir bireyin o kuşağın tüm özelliklerine mutlaka sahip olacağını veya başka bir kuşağın özelliklerine kesinlikle sahip olamayacağını varsaymanın uygun olmayacağını (Jiří, 2016: 107), bu özelliklerin aile üyeleri, arkadaşlar ve iş yerindeki insanlar arasındaki ilişkilerin genel kalıplarının bir göstergesi olduğunu, tarih aralığının bir ucunda veya diğerinde doğan bireylerin önceki veya sonraki kuşaklar ile örtüşen özellikleri gösterebileceğini belirtmektedirler (Jiří, 2016: 109). Bununla birlikte, araştırmacılar bu değerlendirmelerde referans olarak çoğunlukla ABD gibi Batılı kaynakların kullanıldığına dikkat çekmektedir (Kicheva, 2017: 106). Ulusal kültürün kuşaklar arasındaki farkları önemli ölçüde etkilediğini, bu yüzden kuşakların özelliklerinin ülkeden ülkeye farklılık göstereceğini belirten araştırmacılar, her ülkede kuşakların özelliklerini belirlemeye yönelik özel araştırmalar yapılarak her kültürün kendi kuşak taksonomisini tanımlaması gerektiğini vurgulamaktadır (Eriş vd., 2013: 153; Süral Özer, 2016: 358; Kicheva, 2017: 106). Diğer yandan, küreselleşme ile bilgi ve iletişim teknolojilerinin gelişmesi, travmatik olayların küresel olarak deneyimlenmesine neden olmaktadır. Bazı araştırmacılar, bu hususların, kendi ülkelerindeki önceki kuşaklarla kıyaslandığında dünyadaki gençlerin birbirlerine daha çok benzemelerinin önemli bir sebebi olduğunu belirtmekte; bu yüzden "küresel kuşaklar" kavramının geliştirilmesini önermektedir (Eriş vd., 2013: 153). Sonuç olarak, kuşakları ayıran sınırları belirlemenin 
zorluğu, kuşak kavramının "ulusal" ve "küresel" boyutlarının olduğu ve çalışmalarda bu hususların dikkate alınması gerektiği unutulmamalıdır.

\subsection{Kuşă̆}

X Kuşağı, 1965-1979 yılları arasında doğanlar olarak varsayılan ve "Köprü Kuşak", "Görünmez Kuşak", "Kayıp Kuşak", "Survivor Kuşak" gibi çeşitli isimler ile anılan kuşaktır (Zemke vd., 2000: 5; Yusoff ve Kian, 2013: 98; Gross, 2017: 17; Kuran, 2019a: 83). İki gelirli ve/veya boşanmış ailelerden gelen bu kuşağın temsilcileri, "Anahtarlı Çocuklar" olarak da adlandırılmaktadır (Jiř́, 2016: 108; Kicheva, 2017: 107). Türkiye'de ilk renkli televizyonu, ilk cep telefonunu, ilk e-postayı deneyimlemiş X Kuşağı (Kuran, 2019a: 83), ülke nüfusunun yaklaşık \%20'sini oluşturmaktadır (TÜiK, 2020).

Literatürde şüphecilik, formaliteye uymama, özerklik, teşvik, başarılı olma, pozitif katkı sağlama, güçlüklerle mücadele etme, dürüstlük, alçak gönüllü olma, güven inşa etme, X kuşağının temel değerleri arasında gösterilmekte (Jiří, 2016: 108; Kicheva, 2017: 110; Bayramoğlu, 2018: 15-29); araştırmacılar genellikle onları bireysel, özgüven sahibi, bağımsız, yaşamlarını etkileyebilecek konularla karşılaştıklarında taleplerini belirten, muazzam küresel farkındalık sahibi, girişimci, hırslı ve yeni beceriler öğrenmek için istekli, adaptasyon ve öğrenme kabiliyeti yüksek, pragmatik, tedbirli, kuşkucu bireyler olarak tanımlamaktadır (Yusoff ve Kian, 2013: 98; Kicheva, 2017: 110-111; Kuran, 2019a: 24).

İşe ilişkin bakışı "yaşamak için çalışmak" şeklinde özetlenebilecek bu kuşak, iş-yaşam dengesine önem vermekte; bu nedenle esnek çalışma tarzını tercih etmektedir (Zemke vd., 2000: 2; Yusoff ve Kian, 2013: 98; Kicheva, 2017: 107-108; Gross, 2017: 18; Kuran, 2019a: 83). Bununla birlikte, Çetin Aydın ve Başol (2014: 1-15), $X$ Kuşağı temsilcilerinin çoğunun işi bir "geçinme kaynağı" olarak gördüklerini belirtmektedir. Para konusunda ise muhafazakâr olan X Kuşağı, ölçülü davranmakta ve tasarruf etmektedir (Jiř́i, 2016: 108; Kicheva, 2017: 107). Araştırmacılara göre bu kuşak çalışanlar, işlerini yaparken bağımsız çalışmayı ve kendilerine ait yollar bulmayı tercih etmekte (Kicheva, 2017: 107); bürokrasiye ve örgütsel düzenlemelere, özellikle performanslarını zorlayacak prosedürlere düşük tolerans göstermekte; doğrudan ve anında takdir ve ödüllendirme beklemekte (Yusoff ve Kian, 2013: 98); yapıcı ve sürekli geribildirime ihtiyaç duymaktadır (Zemke vd., 2000: 5; Gross, 2017: 18). Teknolojiyi iş yaşamının vazgeçilmez bir unsuru olarak değerlendiren bu kuşak, yeni teknolojiye uyabilme becerisi ile bilgisayar, internet, e-posta gibi teknolojik araçları kişisel ve iş yaşamında kullanmaktadır (Zemke vd., 2000: 5; Yusoff ve Kian, 2013: 98; Gross, 2017: 18; Kicheva, 2017: 110; Taş ve Kaçar, 2019: 643-675). X Kuşağı, şirket gelişiminden daha çok kişisel kariyer gelişimine yatırım yapmayı tercih etmektedir (Kicheva, 2017: 107-108). Yusoff ve Kian (2013: 98), bu kuşak çalışanların gelecekteki kariyer imkanları için şanslarını arttırmak üzere mesleki becerilerini geliştirme istekleri ile motive olduğunu, örgütte kalma veya ayrılma kararlarının temel olarak mesleki gelişim fırsatlarına dayandığını, bu yüzden çoğunun bir örgütte uzun süre kalmakla daha az ilgilendiğini, yeterli ve rekabetçi yetenekleri ile iş değiştirmenin daha yüksek terfi ve maaş fırsatları sağlayacağına inandığını belirtmektedir.

\subsection{Y Kuşă̆}

Y Kuşağı, 1980-1999 yılları arasında doğduğu kabul edilen ve "Patlama Kopyası", “Gelecek Kuşak" “Dijital Kuşak", "Net Kuşağı" gibi farklı isimler ile anılan kuşaktır (Jiří, 2016: 107-108; Gross, 2017: 56). Usenet ve bilgisayarlı bilgi sistemleri gibi sosyal dijital teknolojilerin çevrimiçi hale geldiği bir dönemde dünyaya gelmiş ve bu dijital dünyayı deneyimleyen ilk kuşak olan Y Kuşağı, "Dijital Yerliler" olarak da adlandırılmaktadır (Palfrey ve Gasser, 2017: 1; Kicheva, 2017: 117). Türkiye'de refah ve kriz dönemlerinin iç içe geçtiği yıllarda büyüyen bu kuşak (Kuran, 2019a: 97), ülke nüfusunun yaklaşık \%32'sini oluşturmaktadır (TÜIK, 2020).

Yapılan çalışmalarda gerçekçilik, dürüstlük, alçak gönüllü olma, güven inşa etme, teşvik, özerklik, Y Kuşağının temel değerleri arasında gösterilmektedir (Bayramoğlu, 2018: 15-29; Kicheva, 2017: 110; Jiř́, 2016: 108; Eriş vd., 2013: 150-161). Bayramoğlu (2018: 15-29) tarafından yapılan araştırma, başarılı olma isteğinin, Y kuşağını yaşamda harekete geçiren ilk faktör olduğunu ortaya koymaktadır. KONDA Araştırma ve Danışmanlık Şirketi (2011: 1-28) tarafından yapılan araştırmanın sonuçlarına göre, bu kuşak üyeleri başarıyı en çok "mutluluk/huzur" ve "kariyer" kavramları ile tanımlamakta; ellerinde güç ve para olduğunda kendilerini mutlu hissedeceklerini belirtmektedirler. Ayrıca, bağımsızlık Y Kuşağı için önemli bir diğer husus olarak literatürde yer almaktadır. Nitekim, Sosyal Demokrasi Vakfı (2020: 1-12) tarafından yapılan araştırmanın sonuçları, kendi düşüncelerini özgürce ifade edebilme ile başkalarının düşüncelerini özgürce 
ifade edebilmesinin, bu bireyler için yaşamda en öncelikli hususlar olduğunu göstermektedir. Araştırmacılar, genellikle bu kuşak üyelerini eğlenceli, sosyal, hoşgörülü, kültürel farkındalığı yüksek, değişikliklere kolayca uyum sağlayan, kendine güvenen, cesur, hırslı, girişimci, hedef odaklı, proaktif, yoğun teknoloji kullanan, sabırsız bireyler şeklinde tanımlamaktadır (Zemke vd., 2000: 2; Eriş vd., 2013: 150-161; Kubátová ve Kukelková, 2014: 513; Jiří, 2016: 108; Kicheva, 2017: 110; Ekşili ve Antalyal1, 2017: 90-111).

İşi, hedeflerine ulaşmak için bir araç olarak gören ve parayı harcamak için kazanan Y Kuşağı (Jiř́, 2016: 108), iş-yaşam dengesine önem vermekte; esnek çalışma düzenlemelerini tercih etmektedir ( $\mathrm{Ng}$ vd., 2010: 282; Kubátová ve Kukelková, 2014: 513; Kicheva, 2017: 110). Nitekim, Türkiye'den 300 katılımcının aralarında yer aldığ1 30 ülkede 7900 Y Kuşağ 1 üyesi ile gerçekleştirilen araştırmanın bulguları, kurumlarındaki esnek çalışma uygulamalarının, bu bireylerin kişisel refahlarını, sağlıklarını ve mutluluklarını olumlu yönde etkilediğini, verimliliği, işe bağlılığı ve motivasyonu arttırdığını ortaya koymaktadır (Deloitte, 2017: 1-33). Bu kuşak çalışanlar, sürekli mesleki gelişim fırsatı sunan, ilginç ve anlamlı işler tercih etmektedir ( $\mathrm{Ng}$ vd., 2010: 283; Kubátová ve Kukelková, 2014: 513; Gross, 2017: 103). İş birliği yapmaktan hoşlanan, samimi ve yöneticilerin geribildirim için sürekli hazır oldukları bir çalışma ortamı beklentisine sahip Y Kuşağı çalışanları için, katkılarının örgüt tarafından onaylanması ve değerli görülmesi büyük önem taşımaktadır (Ng vd., 2010: 283; Yusoff ve Kian, 2013: 98; Gross, 2017: 30; Kicheva, 2017: 110-111). Anlık mesaj, e-posta, sesli posta ile diğerleriyle sürekli iletişim halinde ve 7/24 mobil bu kuşak temsilcileri (Jiř́i, 2016: 109; Kicheva, 2017: 110), kişisel yaşamlarını ve çalışma ortamlarını daha ilginç ve verimli kılmak üzere teknolojik tüm imkanları ustalıkla kullanmaktadır (Gross, 2017: 21). Teknolojiyi iş hayatının vazgeçilmez unsurlarından biri olarak değerlendiren Y Kuşağı (Taş ve Kaçar, 2019: 643-675), teknolojinin işleri ile sosyal yaşamları arasındaki çizgiyi belirsizleştirdiği konusunda hemfikirdir (Hays, 2013a: 1-24). Y Kuşağı, açı ve ayrıntılı şekilde tanımlanmış bir kariyer planı istemekte (Gross, 2017: 97); uluslararası kariyeri öncelikli hedefleri arasında göstermektedir (Ng vd., 2010: 283; Kubátová ve Kukelková, 2014: 513; Kuran, 2018: 42-63). Hizlı terfi etme beklentisine sahip bu kuşak çalışanlar (Ng vd., 2010: 281-292; Eriş vd., 2013: 150-161; Taş ve Kaçar, 2019: 643-675), kariyerleri boyunca birçok kez iş değiştirebileceklerini belirtmektedir (Hays, 2013a: 1-24; Hays, 2014: 1-28).

\subsection{Motivasyon}

Motivasyon, dünyada ve örgütsel yaşamda gün geçtikçe hızını arttıran değişim ile birlikte, yönetim alanında güncelliğini koruyan bir konu olarak varlığını sürdürmektedir. Motivasyon kelimesinin kökeni Latincede "hareket etmek" anlamını taşıyan "movere" kelimesine dayanmaktadır (Steers vd., 2004: 379; Adair, 2013: 9). $\mathrm{Bu}$ anlama dayanarak, motivasyon "bireyin belirli bir hedefe ulaşmak için gösterdiği çabaların yoğunluğu, yönü ve kararlılı̆̆ı" şeklinde tanımlanabilir (Schermerhorn, 2012: 362; Yusoff ve Kian, 2013: 99). Tanımdaki üç temel unsurdan biri olan yoğunluk, bireyin ne kadar çok çaba gösterdiğini ifade etmekte olup, motivasyona ilişkin değerlendirmelerde en çok odaklanılan boyuttur. Ancak, çaba bireye veya örgüte fayda sağlayacak bir yönde olmadıkça, yüksek yoğunluğun olumlu performans sonuçlarına yol açması olası değildir. Bu nedenle, çabanın yoğunluğu kadar kalitesi de çok önemlidir. Çabanın, hedeflere yönelik ve bu hedeflerle uyumlu olması gerekmektedir. Motivasyonun son unsuru olan kararlılık ise, bireyin çabasını ne kadar süre koruyabileceğini göstermektedir. Bir hedef doğrultusunda motive olmuş birey, hedefe ilişkin görevleri uzun süre sürdürebilmektedir (Robbins ve Judge, 2013: 236).

Motivasyonu anlamaya ilişkin ilk yaklaşımların Yunan filozofları döneminde yer aldığını ve temel itici güç olarak, bireylerin çabaların zevk almaya ve acı çekmekten kaçınmaya yönelttikleri "hedonizm" kavramına odaklandığını söylemek mümkündür. Bu ilke daha sonra, on yedinci ve on sekizinci yüzyıllarda Locke, Bentham, Mill ve Helvetius gibi filozofların çalışmalarında geliştirilmiştir. On dokuzuncu yüzyılın sonlarına doğru, motivasyon konusu felsefe dünyasından yeni ortaya çıkan psikoloji bilimine geçmeye başlamıştır. Ancak, hedonistik varsayımın ampirik bir içeriğinin olmaması ve test edilemezliği yönündeki görüşlerle birlikte, davranış bilimciler motivasyonu açıklamak için daha deneysel temelli modeller aramaya başlamışlardır. İlk modelleri arasında James, Freud ve McDougall tarafından önerilenlerin de yer aldığı, davranışı oldukça rasyonel olarak görmek yerine, pek çok davranışın içgüdüden kaynaklandığını savunan içgüdüsel teoriler, 1920'lerin başından itibaren teorinin artan kısıtlamaları ortaya çıkmaya başladıkça yerini dürtü veya pekiştirme temelli modellere bırakmıştır. Thorndike, Woodworth ve Hull gibi psikologların öncülügünde teorisyenler, motive olmuş davranışta öğrenme kavramını ortaya koymuş ve şimdiki veya gelecekteki davranışlarla ilgili kararların büyük ölçüde geçmiş davranışla ilişkili ödüllerin sonuçlarından etkilendiğini belirtmiştir. Psikologlar içgüdülere ve itici güçlere odaklanırken, yöneticiler daha pragmatik 
konularla ilgilenmiştir. Burada kilit bir gelişme, Frederick Taylor ve meslektaşlarının bilimsel yönetim hareketindeki çalışmaları olmuştur. Dikkatini giderek artan sanayileşmiş bir dönemde fabrika üretiminin etkinliğine odaklayan, ergonomi, iş eğitimi, performans için ödeme teşvik sistemleri, gelişmiş çalışan seçim teknikleri, işin yeniden tasarımı gibi çalışanların yönetimine ilişkin yeni bir bakış sunan bilimsel yönetim yaklaşımının itibarı, giderek daha karmaşık bir işgücünün yükselişi, şirketin aynı anda çalışan ödüllerini arttırmadan verimliliği en üst düzeye çıkarma çabaları ve sonuçta 1930'larda sendikalaşma hareketlerinin yaygınlaşması ile azalmaya başlamıştır. Bu arada, sosyal bilimciler ve yöneticiler, 1930'larda sosyal etkilerin davranış üzerindeki rolünü dikkate almaya başlamış; grup dinamiğinin rolü ve çalışanların çoklu motivasyonel etkiler ile karmaşık varlıklar olarak görülmesinin gerekliliği, performansta önemli hususlar olarak kabul edilmiştir (Steers vd., 2004: 380-381). 1950'lerde davranışı güçlendiren, yönlendiren, destekleyen ve durduran faktörlere odaklanan içerik teorileri (Fatimah vd., 2015: 23), 1960'lı yılların ortalarından itibaren ise motivasyon sürecindeki bireysel değişkenlerin başlangıcını, sürdürülmesini ve sonlandırılmasını inceleyen süreç teorileri (Barreto vd., 2018: 320), alanın gelişmesine katkı sağlayan önceki görüşler ile birlikte, günümüzde örgütsel yaşamın dinamiklerini anlamada önemli bir rol üstlenmektedir.

Araştırmacılar, motivasyon faktörlerinin bireyler arasında farklılık gösterebileceği gibi, aynı bireyin farklı zaman dilimlerinde de değişebileceğini vurgulamaktadır (Robbins ve Judge, 2013: 236; Kian vd., 2013: 57). Öte yandan, bireyler ortak istek, ihtiyaç ve beklentilere de sahiptir. Nitekim, Herzberg (2017: 45), çok az insanın maaş almadan çalışabileceğini vurgulamaktadır. Bununla birlikte, anlamlı iş, başarılı olma isteği, özerklik (Capital, 2010: 190-193), çekici çevre, kararlara katılım, takdir etme, ödüllendirme, yükselme ve gelişme fırsatları, etkin iletişim (Sökmen, 2013: 114-118), motivasyonu etkileyen bazı hususlar olarak çalışmalarda yer almaktadır. Bu bağlamda, örgütlerin, çalışanların benzerlik ve farklılıklarına ilişkin net bir anlayış ile beklentileri karşılayan uygulamalar ortaya koyarak, "arzu edilen bir çalışma ortamı" yaratmaları en önemli görevleri arasında yer almaktadır.

\subsection{X ve Y Kuşağının Motivasyonunu Etkileyen Faktörler}

Literatürde ortaya koydukları sonuçlar ile $X$ ve $Y$ Kuşağının çalışma yaşamında motivasyonuna 1şık tutan çeşitli yerli ve yabancı araştırmalar yer almaktadır. Can (2018: 1-235), Ankara ili içerisinde faaliyet gösteren 4 ve 5 yıldızlı konaklama işletmelerinde çalışanlar üzerinde gerçekleştirdiği araştırmasında, terfi etme olanaklarının hem X Kuşağı hem de Y Kuşağı için motivasyonu etkileyen en önemli husus olduğunu belirtmektedir. Ayrıca, maaşa yapılacak zamlar, aynı önem sırası ile her iki kuşak çalışanlar tarafından ilk üç faktör arasında gösterilmektedir. X Kuşă̆ı için motivasyonu en çok etkileyen bir diğer husus, önerilerin değerlendirilerek uygulamaya konulması iken, Y Kuşağı için iş yerinde saygı görmek ve kendini değerli hissetmek, motivasyonu en çok etkileyen ilk üç faktörden diğeridir. Aksu ve Doğan (2020: 2040-2060) araştırmalarında, ücret, prim, kara katılma, güvenlik ve sosyal haklar, emeklilik planları, ekonomik ve maddi ödülleri kapsayan ekonomik araçların, X Kuşağı katılımcılar tarafından ilk sırada gösterildiğini belirtmektedir. Y Kuşağı temsilcileri için ise ekonomik araçlar ile çalışma ortamı ve koşullarının iyileştirilmesi, kararlara katılım, etkili iletişim, eğitim ve yükselme imkanları gibi faktörlerin de aralarında yer aldığı örgütsel-yönetsel araçlar, aynı önem sırası ile motivasyonu etkileyen en önemli iki faktör olarak yer almaktadır. Benzer şekilde, Universum tarafından Türkiye'de yapılan araştırmanın sonuçları, iyi bir maaş ile profesyonel eğitim ve gelişimin, Y Kuşağı tarafından ilk iki sırada belirtilen hususlar olduğunu ortaya koymaktadır (Kuran, 2019b: 42-61). Taş ve Kaçar (2019: 643-675) tarafından yapılan araştırmanın sonuçları, iş yaşamında bireye duyulan güvenin hem X Kuşağı hem de Y Kuşağı çalışanları için motivasyonu arttıran önemli bir unsur olduğunu göstermektedir. Çökerdenoğlu (2019: 1-112), öğretmenler üzerinde gerçekleştirdiği çalışmasında, kurumdan değer görme ile yöneticilerden olumlu geribildirim almayı X Kuşağ 1 katılımclarının motivasyonunu arttıran faktörler arasında gösterirken, iş-yaşam dengesizliğinin bu kuşağın motivasyonunu azaltan faktörlerden biri olduğunu belirtmektedir. Araştırmada maaş, hem motivasyonu arttıran hem de azaltan bir faktör olarak X Kuşağı öğretmenler tarafından gösterilmektedir. Y Kuşağı temsilcisi öğretmenler ise, kişisel ve mesleki gelişim ile meslektaşlar arası informel ilişkileri motivasyonu arttıran, bürokratik beklentilerin fazlalı̆̆ı, yönetici desteğinin olmaması, özgürce çalışamama ve teknolojik kısıtları motivasyonu azaltan faktörler arasında belirtmektedir. Baran (2018: 1-98) tarafından otomotiv sektöründe satış danışmanları üzerinde yapılan araştırma, iş ortamının eğlenceli olması, sosyal aktivitelerin düzenlenmesi, çalışma arkadaşları ile anlaşabilme, yöneticinin esnek ve demokratik olması unsurlarını kapsayan ve araştırmada "iş yaşamı" şeklinde tanımlanmış faktörün X Kuşağının motivasyonunda ilk sırada, 
anlamlı bir işin ise ikinci sırada yer aldığını ortaya koymaktadır. Y Kuşağı için yönetici ile iş ortamı ve dışında rahatça iletişim kurabilme, kişisel ofis imkanı, iş yerinin eve yakınlığı, işi kolaylaştırıcı teknolojik imkanlara sahip olma faktörlerini kapsayan "rahat çalışma" şeklinde tanımlanmış unsur ile çalışma saatlerinin esnekliği, işte kendi yöntemlerini kullanabilme ve karar alma sürecine dahil olmayı kapsayan "hareket alanı" şeklinde adlandırılmış faktör, çalışmada sırasıyla en önemli iki husus olarak belirtilmektedir.

Kicheva (2017: 103-121) araştırmasında, X Kuşağı için ahlaklı, sosyal sorumluluk sahibi ve hoşgörülü işvereni, Y Kuşağı için ise kariyer gelişim fırsatlarını, motivasyonda en önemli husus olarak göstermektedir. Çaba ve sonuçların takdir edilmesi, çalışmada her iki kuşak katılımcıların en önemli faktörler arasında gösterdikleri bir diğer unsurdur. Yusoff ve Kian (2013: 97-103) tarafından yapılan araştırmanın sonuçları ise X Kuşağı için çalışma koşulları, işin kendisi, şirket politikası ve yönetimin, Y Kuşağı için terfi, şirket politikası ve yönetim ile çalışma koşullarının sırasıyla en öncelikli hususlar olduğunu ortaya koymaktadır. Raganowicz-Gargasz (2014: 1-109) İrlandalı çalışanlar üzerinde gerçekleştirdiği çalışmasında, maaş, emeklilik maaşı, sağlık planı vb. hususları kapsayan tazminat ve ödüllerin hem X Kuşağı hem de Y Kuşağı temsilcileri için motivasyonda en öncelikli hususlardan biri olduğunu göstermektedir. Benzer şekilde, Hays (2013b: 1-28) tarafından Y Kuşağ1 temsilcisi 1000 Japon üzerinde yapılan araştırma, finansal ödüllerin en önemli faktör olduğunu gösterirken, bu ödüller içerisinde ücret ve primleri, ilk iki sırada belirtmektedir. Fatimah vd. (2015: 22-30) yaptıkları çalışmada, işte güvenlik duygusu, meslektaşlar, astlar ve üstler ile ilişkiler ve çalışma koşullarını kapsayan dışsal motivasyon olarak belirttikleri faktörün, iş performansı ödülleri, sorumluluk netliği, zorlu iş, kariyer netliği unsurlarını kapsayan içsel motivasyon olarak belirttikleri faktörden her iki kuşak için de daha yüksek olduğunu ortaya koymaktadır. Leavitt (2014: 1-117) ise çalışmasında, iş yaşamında zevkli ve eğlenceli faaliyetlere katılmanın, Y Kuşağında X Kuşağına göre daha önemli bir faktör olarak değerlendirildiğini belirtmektedir.

\section{Araştırma Metodolojisi}

$\mathrm{Bu}$ araştırmanın amacı, $\mathrm{X}$ ve $\mathrm{Y}$ Kuşağının çalışma yaşamında motivasyonunu etkileyen faktörleri belirlemektir. Çalışma, nitel araştırma desenlerinden biri olan olgubilim (fenomenoloji) deseninde yürütülmüştür. Olgubilim deseni, farkında olduğumuz ancak, derinlemesine ve ayrıntılı bir anlayışa sahip olmadığımız olgulara odaklanmakta; bu olguları araştırmayı amaçlayan çalışmalar için uygun bir araştırma zemini oluşturmaktadır (Yıldırım ve Şimşek, 2018: 69). Ülkemiz nüfusunun ve işgücünün önemli bir kısmını oluşturduğu için $X$ ve $Y$ Kuşağı temsilcileri araştırma kapsamına alınmış; katılımcıların belirlenmesinde amaçlı örnekleme yöntemlerinden maksimum çeşitlilik örneklemesi kullanılmıştır. Bu yöntemde amaç, göreli olarak küçük bir örneklem oluşturmak ve bu örneklemde çalışılan probleme taraf olabilecek bireylerin çeşitliliğini maksimum derecede yansıtmaktır. Böyle bir araştırma sonucunda ortaya çıkabilecek bulgular ve sonuçlar, herhangi başka bir yöntemle ulaşılan sonuçlara kıyasla daha zengin olabilir. Maksimum çeşitliliğe dayalı bir örneklem oluşturmada amaç, genelleme yapmak için bu çeşitliliği sağlamak değildir; tam tersine çeşitlilik gösteren durumlar arasında ne tür ortaklıkların veya benzerliklerin, aynı ölçüde de farklılıkların var olduğunu bulmaktır (Yıldırım ve Şimşek, 2018: 119-120). Bu amaçla, eğitim düzeyi, sektör, görev, çalışma süresi bakımından çeşitlilik gösteren X Kuşağı temsilcisi 15 kişi ve $Y$ Kuşağı temsilcisi 15 kişi olmak üzere toplam 30 çalışan araştırma örneklemini oluşturmaktadır.

Araştırmada veri toplamak üzere görüşme yöntemi kullanılmıştır. Araştırmacı tarafından hazırlanan görüşme formu, ilgili alandan iki araştırmacının görüşleri ışığında revize edilmiş ve son şekli verilmiştir. Katılımcıların demografik özellikleri ve çalışma durumlarına ilişkin sorular ile motivasyonu azaltan ve arttıran faktörler ve işletmeden beklentilere ilişkin soruların yer aldığı yarı yapılandırılmış görüşme formu ile veri toplanmıştır. Araştırmada ses kayıt cihazı da kullanılmak istenmiş; ancak katılımcıların çoğu bu konuda olumsuz veya çekimser görüş bildirdikleri için, bu veri toplama aracı çalı̧̧maya dahil edilmemiştir. Veriler Ocak-Şubat 2019 olmak üzere iki aylık bir dönemde toplanmış olup, her bir katılımcı ile 20-30 dakika süren görüşmeler yapılmıştır. Her bir katılımcı ile yapılan görüşmenin hemen sonunda, araştırmacı tarafından toplanan veriler özetlenmiş; katılımcılara eklemek istedikleri hususlar olup olmadığı sorulmuş; ilave değerlendirmeler yazılmış ve görüşmeden elde edilen tüm bilgilerin görüşme formuna doğru yansıtıldığına ilişkin katılımcı teyidi alınarak görüşme sonlandırılmıştır.

Veriler, içerik analizi yöntemi ile analiz edilmiştir. İçerik analizi, hacimli olan nitel materyali alarak temel tutarlılıkları ve anlamları belirlemeye yönelik herhangi bir nitel veri indirgeme ve anlamlandırma girişimlerini 
ifade etmektedir (Patton, 2014: 453). Bu çerçevede, öncelikle X Kuşağ için X1'den X15'e, Y Kuşağ1 için Y1'den Y15'e kadar belirlenen katılımcı kodları, görüşme formlarına eklenmiştir. Sonrasında, tüm formlar, araştırmacı tarafından birkaç kez dikkatlice okunarak ilgili kavramsal çerçeve ışığında kodlamalar yapılmış ve temalar ortaya çıkarılmıştır. Bu aşamada uzman görüşüne başvurulmuş, alandan iki araştırmacının geribildirimleri doğrultusunda kodlamalar ve temalar revize edilmiştir. Son şekli verilen temalar ile bulgular ortaya konmuş; bulguları desteklemek amacıyla katılımcıların kendi ifadelerinden alıntılara yer verilmiştir.

Araştırmanın geçerliğini ve güvenirliğini sağlamak amacıyla, Yıldırım ve Şimşek (2018: 277) tarafından belirtilen bazı stratejiler kullanılmıştır. Bu çerçevede çeşitleme, uzman incelemesi, katılımcı teyidi, ayrıntılı betimleme ve amaçlı örnekleme yöntemlerine başvurulmuştur. Yukarıda belirtildiği üzere, veri kaynaklarının çeşitliliğini sağlamak üzere araştırmaya farklı özelliklere sahip katılımcılar dahil edilmiştir. Bununla birlikte, görüşme formunun oluşturulması ile kodların ve temaların oluşturulması aşamalarında uzman görüşüne başvurulmuş; görüşmelerden elde edilen veriler ise katılımcılar tarafından teyit edilmiştir. Ayrıca, araştırmada doğrudan alıntılar ile ayrıntılı betimleme yapılmış; aktarılabilirliği arttırmayı sağlayan amaçlı örnekleme yöntemi kullanılmıştır.

\section{Bulgular}

X Kuşağı ve Y Kuşağı temsilcisi çalışanların demografik özellikleri ve çalışma durumları ile ilgili bilgiler ve motivasyonlarına ilişkin cevaplar, aşağıdaki bölümlerde ayrıntıları ile yer almaktadır.

Katılımcıların demografik özellikleri ve çalışma durumlarına ilişkin bilgiler Tablo 1'de gösterilmiştir. X Kuşağı katılımcılarının 8'i kadın, 7'si erkek olup, yaşları 40 ile 53 arasındadır. Eğitim düzeyleri ilköğretim ile yüksek lisans arasında çeşitlilik gösteren katılımcılar, eğitim, yiyecek-içecek hizmetleri, plastik ürünleri, sağlık, perakende, gıda, tekstil, turizm otelcilik, inşaat, bankacilık ve telekomünikasyon olmak üzere çeşitli sektörlerde ve farklı görevlerde çalışmaktadır. Toplam mesleki deneyimleri 6 ile 33 yıl arasında değişen çalışanların, şu an görev yaptıkları kurumda çalışma süreleri ise 1 ile 11 yıl arasındadır. 9'u erkek, 6'sı kadın olan Y Kuşağı katılımcılarının yaşları 25 ile 35 arasında olup, çoğunluğu lisans mezunudur. Toplam mesleki deneyimleri 2 ile 10 yıl, şu an bulundukları kurumda çalışma süreleri 6 ay ile 5 yıl arasında değişen katılımcılar, gümrük müşavirlik, gayrimenkul değerleme ve danışmanlık, sağlık, tekstil, yönetim yazılımları, bankacılık, enerji, perakende, vergi, inşaat malzemeleri, güvenlik, inşaat ve AVM işletmeciliği, demir-çelik üretim ve eğlence-oyun olmak üzere farklı sektörlerde ve görevlerde çalışmaktadır.

Tablo 1. Katılımcıların Demografik Özellikleri ve Çalışma Durumlarına İlişkin Bilgiler

\begin{tabular}{|c|c|c|c|c|c|c|c|}
\hline $\begin{array}{c}\text { Katılımcı } \\
\text { Kodu }\end{array}$ & Cinsiyet & Yaş & $\begin{array}{c}\text { Eğitim } \\
\text { Düzeyi }\end{array}$ & Sektör & Görev & $\begin{array}{c}\text { Kurumda } \\
\text { Çalışma } \\
\text { Süresi }\end{array}$ & $\begin{array}{c}\text { Toplam } \\
\text { Çalışma } \\
\text { Süresi }\end{array}$ \\
\hline X1 & Kadın & 53 & Lisans & Eğitim & Öğretmen & 2 yıl & 25 yıll \\
\hline X2 & Erkek & 48 & İlköğretim & $\begin{array}{c}\text { Yiyecek İçecek } \\
\text { Hizmetleri }\end{array}$ & Aşçı & 5 yıl & 33 yıll \\
\hline X3 & Erkek & 47 & Lisans & Eğitim & Ö̆ğretmen & 11 yıl & 24 yıl \\
\hline X4 & Erkek & 43 & Lise & Plastik Ürünleri & $\begin{array}{c}\text { Güvenlik } \\
\text { Personeli }\end{array}$ & 2 yıl & 20 yıl \\
\hline X5 & Erkek & 44 & Lisans & Eğitim & Müdür & 4 yıl & 20 yıl \\
\hline X6 & Kadın & 40 & İlköğretim & Sağlı & $\begin{array}{c}\text { Temizlik } \\
\text { Personeli }\end{array}$ & 2 yıl & 14 yıl \\
\hline X7 & Erkek & 42 & Lisans & Perakende & $\begin{array}{c}\text { Mağaza } \\
\text { Müdürü }\end{array}$ & 4 yıl & 14 yıl \\
\hline X8 & Kadın & 40 & İlköğretim & Gıda & $\begin{array}{c}\text { Çay ve Temizlik } \\
\text { Elemanı }\end{array}$ & 1 yıl & 6 yıl \\
\hline X9 & Kadın & 41 & Lise & Tekstil & Tasarımc1 & 4 yıl & 25 yıl \\
\hline X10 & Erkek & 40 & $\begin{array}{c}\text { Yüksek } \\
\text { Lisans }\end{array}$ & Eğitim & Öğretmen & 4 yıl & 15 yıl \\
\hline X11 & Kadın & 40 & Lise & $\begin{array}{c}\text { Turizm ve } \\
\text { Otelcilik }\end{array}$ & Kat Görevlisi & 2 yıl & 8 yıl \\
\hline
\end{tabular}


E. Yildiz 13/1 (2021) 216-234

\begin{tabular}{|c|c|c|c|c|c|c|c|}
\hline $\mathrm{X} 12$ & Erkek & 45 & $\begin{array}{l}\text { Yüksek } \\
\text { Lisans }\end{array}$ & Eğitim & Öğretmen & 4 yıl & $15 \mathrm{y}$ ll \\
\hline $\mathrm{X} 13$ & Kadın & 43 & $\begin{array}{l}\text { Yüksek } \\
\text { Lisans }\end{array}$ & İnşaat & $\begin{array}{c}\text { Halkla İlişkiler } \\
\text { Yöneticisi }\end{array}$ & 4 yıl & $18 \mathrm{y} 1 \mathrm{l}$ \\
\hline X14 & Kadın & 42 & Lisans & Bankacılık & $\begin{array}{l}\text { Sermaye } \\
\text { Yönetimi } \\
\text { Uzmanı }\end{array}$ & 2 yil & $15 \mathrm{y} 1 \mathrm{l}$ \\
\hline X15 & Kadın & 40 & Lisans & Telekomünikasyon & $\begin{array}{l}\text { Saha Satış } \\
\text { Yöneticisi }\end{array}$ & 2 yıl & $14 \mathrm{y} 1 \mathrm{l}$ \\
\hline $\mathrm{Y} 1$ & Erkek & 27 & $\begin{array}{l}\text { Yüksek } \\
\text { Lisans } \\
\end{array}$ & $\begin{array}{c}\text { Gümrük } \\
\text { Müşavirlik }\end{array}$ & $\begin{array}{l}\text { Muhasebe ve } \\
\text { Finans Müdürü }\end{array}$ & 5 yil & 5 yil \\
\hline $\mathrm{Y} 2$ & Erkek & 27 & Lisans & $\begin{array}{l}\text { Gayrimenkul } \\
\text { Değerleme ve } \\
\text { Danışmanlık }\end{array}$ & $\begin{array}{c}\text { Gayrimenkul } \\
\text { Değerleme } \\
\text { Uzmanı } \\
\end{array}$ & 2 yil & 2 yil \\
\hline $\mathrm{Y} 3$ & Kadın & 33 & $\begin{array}{l}\text { Yüksek } \\
\text { Lisans } \\
\end{array}$ & Sağlık & Hemşire & 6 ay & 9 yil \\
\hline $\mathrm{Y} 4$ & Erkek & 28 & Lisans & Tekstil & $\begin{array}{c}\text { Müşteri } \\
\text { Temsilcisi } \\
\end{array}$ & 3 yil & 6 yil \\
\hline Y5 & Kadın & 30 & Lisans & Sağlık & $\begin{array}{l}\text { Satınalma } \\
\text { Uzmanı }\end{array}$ & 1 yıl & $10 \mathrm{y} 1 \mathrm{l}$ \\
\hline $\mathrm{Y} 6$ & Erkek & 25 & Lisans & $\begin{array}{l}\text { Yönetim } \\
\text { Yazılımları }\end{array}$ & $\begin{array}{c}\text { Uygulama } \\
\text { Kıdemli Uzmanı }\end{array}$ & 1 yıl & 8 yil \\
\hline $\mathrm{Y} 7$ & Kadın & 25 & Lisans & Bankacilık & $\begin{array}{c}\text { Müşteri } \\
\text { Danışmanı }\end{array}$ & $1,5 \mathrm{y} 1 \mathrm{l}$ & 3 yil \\
\hline Y8 & Erkek & 32 & Lisans & Enerji & $\begin{array}{l}\text { Bayii A ğ1 } \\
\text { Yöneticisi }\end{array}$ & 2,5 yil & 6 yil \\
\hline Y9 & Kadın & 31 & $\begin{array}{l}\text { Yüksek } \\
\text { Lisans } \\
\end{array}$ & Perakende & $\begin{array}{c}\text { Eğitim ve } \\
\text { Gelişim Uzmanı }\end{array}$ & 3,5 y1l & 9 yil \\
\hline Y10 & Erkek & 30 & Lisans & Kamu-Vergi & $\begin{array}{l}\text { Vergi İnceleme } \\
\text { Uzmanı }\end{array}$ & 4,5 y1l & 8 yil \\
\hline Y11 & Erkek & 27 & Lisans & İnşaat Malzemeleri & $\begin{array}{l}\text { Bölge Satış } \\
\text { Temsilcisi }\end{array}$ & 3 yil & 3 yil \\
\hline Y12 & Kadın & 25 & Lisans & $\begin{array}{l}\text { İnşaat ve AVM } \\
\text { İşletmeciliği }\end{array}$ & $\begin{array}{c}\text { İnsan } \\
\text { Kaynakları } \\
\text { Personeli } \\
\end{array}$ & 2,5 yil & 2,5 y1l \\
\hline Y13 & Erkek & 32 & Lisans & Güvenlik & $\begin{array}{c}\text { İnsan } \\
\text { Kaynakları } \\
\text { Personeli }\end{array}$ & 4,5 yil & $10 \mathrm{y} 1 \mathrm{l}$ \\
\hline Y14 & Kadın & 35 & Lisans & $\begin{array}{c}\text { Demir-Çelik } \\
\text { Üretim }\end{array}$ & $\begin{array}{l}\text { Satınalma } \\
\text { Müdürü }\end{array}$ & 4 yıl & $10 \mathrm{y} 1 \mathrm{l}$ \\
\hline Y15 & Erkek & 25 & Lisans & Eğlence-Oyun & $\begin{array}{c}\text { Projeler } \\
\text { Süpervizörü }\end{array}$ & 2 yıl & 6 yil \\
\hline
\end{tabular}

X Kuşağı katılımcılarının motivasyonunu azaltan faktörler Tablo 2'de yer almaktadır. Motivasyonu azaltan hususlara ilişkin alınan 45 cevabın üçte birini geciken ve yetersiz ücret, çalışanların sorumluluklarını yerine getirmemesi ve görev tanımlarının belirsizliği faktörleri oluşturmaktadır. Uzun ve yorucu çalışma saatleri, çalışma arkadaşları ile uyumsuzluk, dedikodu, yöneticilerin bilgi ve beceri eksikliği, dikkat çeken diğer dört faktördür. İzleyen cevapların, ödüllendirme sisteminin olmayışı, kaynakların yetersiz olması, nitelikli personel eksikliği, iş süreçlerinde şeffaf olmama, adam kayırmacılık ve çalışanı küçümseme şeklinde olduğu görülmektedir. Son sırada yer alan faktörler ise katı hiyerarşik yapı, düşük düzeyde kararlara katılım, sert ve kaba iletişim, iş güvencesizliği, çalışanların birbirlerinin yaptıkları işleri gözetlemesi ve sosyal aktivitelerin yetersizliği şeklinde belirtilmiştir. 
Katılımcıların motivasyonunu azaltan faktörlere ilişkin kendi ifadelerinden bazıları aşağıda gösterilmiştir.

"Ülkedeki ekonomik belirsizliklerin doğal olarak kuruma yansımasından kaynaklanan maaşların zamanında ödenememesi, maaş zamlarının yok denecek kadar az olması motivasyonumu ciddi ölçüde düşürüyor." (X5)

"İnsanların başkalarının işlerini takip edip -okula geliş gidiş saatlerini ya da ders programlarını karşılaştırmaș- kendi işlerini yapmaması çok can sıkıcı bir durum." (X10)

"Kendi işinden başka işleri de yapmak, sen çalışırken başkalarının oturması, sonra onların işinin de sana yüklenmesi, en çok yaşadı̆̆ım sıkıntılar bunlar." (X11)

Tablo 2. X Kuşağının Motivasyonunu Azaltan Faktörler

\begin{tabular}{|l|c|c|}
\hline Tema & f & \% \\
\hline Zamanında ödenmeyen ve yetersiz ücret & 6 & 13,4 \\
\hline Sorumluluklarını yerine getirmeyen çalışanlar & 5 & 11,2 \\
\hline Belirsiz görev tanımları & 4 & 9,0 \\
\hline Uzun ve yorucu çalışma saatleri & 3 & 6,7 \\
\hline Çalışma arkadaşları ile uyumsuzluk & 3 & 6,7 \\
\hline Kurum içi dedikodu & 3 & 6,7 \\
\hline Yöneticilerin bilgi ve beceri eksikliği & 3 & 6,7 \\
\hline Ödüllendirme sisteminin olmaması & 2 & 4,4 \\
\hline Kaynakların yetersizliği & 2 & 4,4 \\
\hline Nitelikli personel eksikliği & 2 & 4,4 \\
\hline İş süreçlerinde şeffaf olmama & 2 & 4,4 \\
\hline Adam kayırmacılık & 2 & 4,4 \\
\hline Çalışanı küçümsemek & 2 & 4,4 \\
\hline Katı hiyerarşik yapı & 1 & 2,2 \\
\hline Kararlara katılımın düşük düzeyde olması & 1 & 2,2 \\
\hline Kurum içi sert ve kaba iletişim dili & 1 & 2,2 \\
\hline İş güvencesizliği & 1 & 2,2 \\
\hline Çalışanların birbirlerini gözetlemesi & 1 & 2,2 \\
\hline Sosyal etkinliklerin yetersizliği & 1 & 2,2 \\
\hline Toplam & $\mathbf{4 5}$ & $\mathbf{1 0 0}$ \\
\hline
\end{tabular}

Tablo 3, X Kuşağı katılımcılarının motivasyonunu arttıran faktörleri göstermektedir. X Kuşağı çalışanlar, anlayışlı, güler yüzlü ve uyumlu çalışma arkadaşlarını, motivasyonu arttıran en önemli husus olarak belirtmişlerdir. Ardından gelen iki faktör, saygı ve hoşgörü gösterilmesi ile ücret artışı şeklindedir. İzleyen cevaplar, işte başarı, özerklik, ödüllendirme sisteminin varlı̆̆ı, etkin iletişim ve geribildirim, yönetim tarafından çalışan problemlerine hızlı ve etkili çözümler bulunması, çalışanlar arasında ayrımcılık yapılmaması, dedikodu yapılmaması, genç kuşak ile birlikte olma ve sosyal etkinlikler şeklinde sıralanmıştır. İşi sevmek, takdir edilmek, eğitim düzeyi yüksek çalışanlar, anlayışlı, çalışana güven duyan yöneticiler, açık ve net görev tanımları, dinamik çalışma ortamı ve iş anlayışı, iş bölümü ve hiyerarşide düzen ve uyum ile kurum başarısı, motivasyonu arttıran diğer faktörler olarak yer almaktadır.

Katılımcıların motivasyonunu arttıran faktörlere ilişkin kendi ifadelerinden bazılarına aşağıda yer verilmiştir.

“Bütün personelin ve çalışma arkadaşlarımın güler yüzlü ve anlayışlı olması motivasyonumu yükseltiyor." (X15)

"Bana ve tüm iş arkadaşlarıma saygı gösterilmesi, güzel muamele edilmesi çalışmamdaki en önemli kriter." (X12)

"Bu şirkette çalışanların hakları önemseniyor; aldı̆̆ım maaş da iyi ama daha yüksek olsa daha da memnun olurum tabi ki." (X9) 
Tablo 3. X Kuşağının Motivasyonunu Arttıran Faktörler

\begin{tabular}{|l|c|c|}
\hline Tema & f & \% \\
\hline Anlayışlı, güler yüzlü ve uyumlu çalışma arkadaşları & 9 & 21,0 \\
\hline Çalışana saygı ve hoşgörü gösterilmesi & 4 & 9,5 \\
\hline Ǘret artışı & 3 & 7,1 \\
\hline İşte başarılı olmak & 2 & 4,8 \\
\hline Özerk çalışma alanı & 2 & 4,8 \\
\hline Ödüllendirme sisteminin olması & 2 & 4,8 \\
\hline Etkin iletişim ve geribildirim & 2 & 4,8 \\
\hline Yönetimin, çalışanların problemlerine hızlı ve etkili çözümler bulması & 2 & 4,8 \\
\hline Çalışanlar arasında ayrımcılık yapılmaması & 2 & 4,8 \\
\hline Dedikodu yapılmaması & 2 & 4,8 \\
\hline Genç kuşak ile bir arada olmak & 2 & 4,8 \\
\hline Sosyal etkinliklerin düzenlenmesi & 2 & 4,8 \\
\hline İşi sevmek & 1 & 2,4 \\
\hline Takdir edilmek & 1 & 2,4 \\
\hline Eğitim düzeyi yüksek çalışanlar & 1 & 2,4 \\
\hline Anlayışlı, çalışana güven duyan yöneticiler & 1 & 2,4 \\
\hline Açık ve net görev tanımları & 1 & 2,4 \\
\hline Dinamik çalışma ortamı ve iş anlayışı & 1 & 2,4 \\
\hline İş bölümü ve hiyerarşide düzen ve uyum & 1 & 2,4 \\
\hline Kurumun başarılı olması & 1 & 2,4 \\
\hline Toplam & 1 & $\mathbf{1 0 0}$ \\
\hline
\end{tabular}

X Kuşağı katılımcılarının, çalıştıkları kurumlardan beklentileri Tablo 4’te gösterilmiştir. Bu kuşak çalışanların ilk sırada yer alan beklentisi, ücret artışıdır. Cazip yan haklar ise ikinci sırada gelmektedir. İzleyen iki beklenti, ödüllendirme sisteminin kurulması ile günün koşullarına uygun çalışma araç-gereçlerinin sağlanması şeklindedir. Ardından belirtilen hususlar, ihtiyaç duyulan kaynakların sağlanması, çalışan haklarına saygı gösterilmesi, ayrımcılık yapılmaması, çalışma ortamının huzurlu olması, birimler arasında iş birliği ve sosyokültürel etkinliklerdir. Daha az iş yükü, etkin iletişim ve geribildirim, çalışan sorunlarına zaman ayrılması, fikirleri özgürce ifade edebilme fırsatı, açık ve net görev tanımları, iş güvencesi, sosyal yardımlar ve kurumun başarılı olması, diğer beklentiler olarak sıralanmaktadır.

Katılımcıların beklentilerine ilişkin kendi ifadelerinden bazıları aşağıda yer almaktadır.

"Indirim, özel gün, tatil gibi dönemlerde çok yoğun çalışıyoruz; fazla mesai için yol yardımı almak veya bu yoğun zamanların telafisini yapabileceğimiz ekstra tatil gibi haklara çok ihtiyacımız var." (X7)

"Yıl boyunca fazladan birçok üniversite gezisi, sınav, seminer düzenledim. Öğrenciler ve veliler çok memnun oldu ama yönetim bu çabamı ödüllendirmedi. Çünkü kurumda ödül politikası diye bir şey yok." (X3)

"Bu kurum değişen koşullara ayak uydurmak zorunda. Bir akıllı tahta bile benim işimi daha eğlenceli hale getirebilecek. Söylememe rağmen, olumlu bir sonuç yok." (X1) 
Tablo 4. X Kuşağının İşletmeden Beklentileri

\begin{tabular}{|l|c|c|}
\hline Tema & f & \% \\
\hline Ücret artışı & 8 & 21,1 \\
\hline Cazip yan haklar sunulması & 4 & 10,5 \\
\hline Ödüllendirme sisteminin kurulması & 3 & 7,9 \\
\hline Günün koşullarına uygun çalışma araç-gereçlerinin sağlanması & 3 & 7,9 \\
\hline İhtiyaç duyduğu kaynakların çalışana verilmesi & 2 & 5,3 \\
\hline Çalışan haklarına saygı gösterilmesi & 2 & 5,3 \\
\hline Çalışanlar arasında ayrımcılık yapılmaması & 2 & 5,3 \\
\hline Huzurlu çalışma ortamı & 2 & 5,3 \\
\hline Birimler arası iş birliği & 2 & 5,3 \\
\hline Sosyo-kültürel etkinlikler & 2 & 5,3 \\
\hline Daha az iş yükü & 1 & 2,6 \\
\hline Etkin iletişim ve geribildirim & 1 & 2,6 \\
\hline Yönetimin çalışanların sorunlarına zaman ayırması & 1 & 2,6 \\
\hline Fikirleri özgürce dile getirme fırsatlarının sağlanması & 1 & 2,6 \\
\hline Açı ve net görev tanımları & 1 & 2,6 \\
\hline İş güvencesi & 1 & 2,6 \\
\hline Sosyal yardımlar & 1 & 2,6 \\
\hline Kurumun başarılı olması & 1 & 2,6 \\
\hline Toplam & 1 & $\mathbf{1 0 0}$ \\
\hline
\end{tabular}

Y Kuşağı katılımcılarının motivasyonunu azaltan faktörler Tablo 5'te yer almaktadır. Gereksiz, uzun ve yavaş bürokratik süreçler, bu kuşak çalışanlar tarafından motivasyonu azaltan en önemli husus olarak gösterilmiştir. İkinci sırada ise fiziki çalışma koşullarının yetersizliği gelmektedir. Yetersiz ücret, kariyer planlama ve geliştirme uygulamalarının eksikliği, fazla ve dengesiz dağıtılmış iş yükü, katı hiyerarşik yapı, iletişim sorunları ve adam kayırmacılık, dikkat çeken diğer faktörlerdir. İzleyen cevaplar, özerklik verilmemesi, değer görmeme, hedeflerin tutturulması konusunda baskı yapılması, fikirleri ve yetenekleri ortaya koymaya izin vermeyen örgüt kültürü ile yönetici ve iş arkadaşları ile fikir ayrılıkları kaynaklı çatışmalar şeklindedir. Saygı gösterilmemesi, takdir edilmeme, prim sistemi ve yan haklarda yapılan anlık değişiklikler, ardından gelen diğer üç faktördür. Sonrasında gelen hususların ise çalışana güvensizlik, esnek çalışma imkanlarının olmayışı, ödüllendirme sisteminin olmaması, eğitim ve geliştirme faaliyetlerinin yetersizliği, görev tanımlarının belirsizliği, yöneticilerin bilgi ve beceri eksikliği, yönetimin misyon ve amaç inşa edememesi, birimler arasındaki hak ayrıcalıkları, nitelikleri benzer olmayan kişilerin aynı pozisyonda çalıştırılması, iyi niyetli davranışların suiistimal edilmesi ve içeriği belirsiz, etkisiz toplantılar şeklinde olduğu görülmektedir.

Katılımcıların motivasyonunu azaltan faktörlere ilişkin kendi ifadelerinden bazılarına aşağıda yer verilmiştir.

"Süreçler ve akışlar çok yavaş ilerliyor; bürokrasi her an kendini gösteriyor. Bunlar olmasın demiyorum fakat hızl ve akıct ilerlememe engel olan sebepler de bunlar. Bu yüzden zaman zaman motivasyonum düşüyor." (Y6)

"Ofisin düzenli ve hijyenik olmaması motivasyonumu bozuyor. Ayrıca, açı ofiste çalıştığımdan dolayı gürültü kirliliği çalışma performansımı ve motivasyonumu engelliyor." (Y4)

"Motivasyonumu en çok etkileyen faktörlerden birisi, iş dă̆̆lımının adaletsiz olması. Yani ben bir sürü işle aynı anda uğraşırken, benim yaptı̆̆ım işi diğerleri tüm güne yayarak yapıyor. Bu durumda ben ilerlemeyi beklerken ve yardım edilmesi gereken ben iken, işleri bitirdiğim için ben yardımcı olurken buluyorum kendimi." (Y13) 
Tablo 5. Y Kuşağının Motivasyonunu Azaltan Faktörler

\begin{tabular}{|l|c|c|}
\hline Tema & f & \% \\
\hline Gereksiz, uzun ve yavaş bürokratik süreçler & 7 & 10,3 \\
\hline Fiziki çalışma koşullarının yetersizliği & 5 & 7,4 \\
\hline Yetersiz ücret & 4 & 5,9 \\
\hline Kariyer planlama ve geliştirme uygulamalarının eksikliği & 4 & 5,9 \\
\hline İş yükünün fazla ve dengesiz dağıtımı & 4 & 5,9 \\
\hline Katı hiyerarşik yapı & 4 & 5,9 \\
\hline İletişim sorunları & 4 & 5,9 \\
\hline Adam kayırmacılık & 4 & 5,9 \\
\hline Çalışana işinde özerklik verilmemesi & 3 & 4,4 \\
\hline Çalısana değer verilmemesi & 3 & 4,4 \\
\hline Hedeflerin tutturulması konusunda baskı yapılması & 3 & 4,4 \\
\hline Fikirleri ve yetenekleri ortaya koymaya izin vermeyen örgüt kültürü & 3 & 4,4 \\
\hline Yönetici ve iş arkadaşları ile fikir ayrılıkları kaynaklı çatışmalar & 3 & 4,4 \\
\hline Çalışana saygı gösterilmemesi & 3 & 2,8 \\
\hline Yapılan işin takdir edilmemesi & 2 & 2,8 \\
\hline Prim sistemi ve yan haklarda yapılan anlık değişiklikler & 2 & 2,8 \\
\hline Çalışana güvenmeme & 2 & 1,5 \\
\hline Esnek çalışma imkanlarının olmaması & 1 & 1,5 \\
\hline Ödüllendirme sisteminin olmaması & 1 & 1,5 \\
\hline Eğitim ve geliştirme faaliyetlerinin yetersizliği & 1 & 1,5 \\
\hline Belirsiz görev tanımları & 1 & 1,5 \\
\hline Yöneticilerin bilgi ve beceri eksikliği & 1 & 1,5 \\
\hline Yönetimin misyon ve amaç inşa edememesi & 1 & 1,5 \\
\hline Birimler arası hak ayrıcalıkları & 1 & 1,5 \\
\hline Nitelikleri benzer olmayan çalısanların aynı pozisyonda çalıştırılması & 1 & 1,5 \\
\hline İyi niyetli davranışların suiistimal edilmesi & 1 & 1,5 \\
\hline İçeriği belirsiz, etkisiz toplantılar & 1 & 1,5 \\
\hline Toplam & 1 & $\mathbf{6 8}$ \\
\hline
\end{tabular}

Tablo 6, Y Kuşağı katılımcılarının motivasyonunu arttıran faktörleri göstermektedir. Y Kuşağ çalışanlar, samimi ve huzurlu çalışma ortamını, motivasyonu arttıran en önemli husus olarak belirtmişlerdir. Esnek çalışma ve kararlara katılım imkanının sağlanması, dikkat çeken diğer iki faktördür. Ardından gelen diğer üç cevap, başarıların takdir edilmesi ve ödüllendirilmesi, etkin iletişim ve geribildirim ile güler yüzlü, yardımsever, anlayışlı yöneticiler şeklindedir. İzleyen hususlar, uzun süreli dostluklar ve çalışma arkadaşlarının desteği, değer verilmesi, saygı görme, adam kayırmacilıktan uzak durulması, kültürel zenginliğe sahip, öğrenme sağlayan çalışma ortamı, yetki ve sorumluluk verilmesi, iş garantisi, prim sistemi ve yan haklar ile sosyal aktiviteler şeklinde sıralanmıştır. Sonrasında ise çalışana güven duyma, özerklik, kariyer planlaması ve terfi imkanlarının varlığı, eğitim ve geliştirme faaliyetleri, ücretlerin zamanında ödenmesi, zam oranlarının adil olması, benzer yaş grupları ile çalışma, denk yetki ve yeterlilik seviyesinde çalışma arkadaşları faktörleri yer almaktadır.

Katılımcıların motivasyonunu arttıran faktörlere ilişkin kendi ifadelerinden bazıları aşağıda gösterilmiştir.

"Ekip ortaminda her sabah mutlaka bir araya geliyoruz. Zaman varsa kahvaltı, kısa bir vakit varsa mutlaka çay, kahve sohbetlerimiz oluyor. Bunun bir zorunluluk olmadığını bilmek ve arkadaşlarımızla buluşuyormuş gibi olması işe erken gitmemi ve güne güzel başlamamı sağhlyor." (Y7)

"Esnek çalı̧ma saatleri ve pozisyonum için izin günlerini kendim belirliyor olmam, çok motive edici bir durum." (Y15)

"Bir konuda değişiklik yapılacaksa, mutlaka çalışanlara soruluyor. Hazırladığımız rapor veya projelerde değişiklik yapılırken mutlaka fikrimiz alınıyor." (Y9) 
Tablo 6. Y Kuşağının Motivasyonunu Arttıran Faktörler

\begin{tabular}{|l|c|c|}
\hline Tema & f & \% \\
\hline Samimi ve huzurlu çalışma ortamı & 6 & 12,2 \\
\hline Esnek çalışma imkanlarının olması & 4 & 8,3 \\
\hline Kararlara katılım imkanının sağlanması & 4 & 8,3 \\
\hline Başarıların takdir edilmesi ve ödüllendirilmesi & 3 & 6,1 \\
\hline Etkin iletişim ve geribildirim & 3 & 6,1 \\
\hline Güler yüzlü, yardımsever, anlayışlı yöneticiler & 3 & 6,1 \\
\hline Uzun süreli dostluklar ve çalışma arkadaşlarının desteği & 2 & 4,1 \\
\hline Çalışana değer verilmesi & 2 & 4,1 \\
\hline Saygı görmek & 2 & 4,1 \\
\hline Adam kayırmacılıktan uzak durulması & 2 & 4,1 \\
\hline Kültürel zenginliğe sahip, öğrenme sağlayan çalışma ortamı & 2 & 4,1 \\
\hline Yetki ve sorumluluk verilmesi & 2 & 4,1 \\
\hline İş garantisi & 2 & 4,1 \\
\hline Prim sistemi ve yan hakların olması & 2 & 4,1 \\
\hline Sosyal etkinlikler & 2 & 4,1 \\
\hline Çalışana güven duyulması & 2 & 2,0 \\
\hline Özerklik & 1 & 2,0 \\
\hline Kariyer planlaması ve terfi imkanlarının varlığı & 1 & 2,0 \\
\hline Eğitim ve geliştirme faaliyetleri & 1 & 2,0 \\
\hline Ücretlerin zamanında ödenmesi & 1 & 2,0 \\
\hline Zam oranlarının adil olması & 1 & 2,0 \\
\hline Benzer yaş grupları ile çalışma & 1 & 2,0 \\
\hline Çalışma arkadaşlarının denk yetki ve yeterlilik seviyesinde olması & 1 & 2,0 \\
\hline Toplam & 1 & $\mathbf{1 0 0}$ \\
\hline
\end{tabular}

Y Kuşağı katılımcılarının, çalıştıkları kurumlardan beklentileri Tablo 7'de gösterilmiştir. Ücret artışı, bu kuşak çalışanların ilk sırada yer alan beklentisidir. Dikkat çeken diğer iki faktör, kariyer planlama uygulamalarına ve terfi imkanlarına yer verilmesi ile çalışana değer verilmesi şeklindedir. İlk üç sırada yer alan bu beklentiler, alınan 60 cevabın üçte birini oluşturmaktadır. Eğitim ve geliştirme fırsatları ile prim, yan haklar ve sosyal yardımlar, belirtilen diğer iki faktördür. Ardından gelen hususların ise fiziki çalışma koşullarının iyileştirilmesi, etkin kişilerarası ilişki ve iletişim ortamının sağlanması, yönetim tarafından çalışanlara amaçlar ile uyumlu ve gerçekçi hedefler belirlenmesi, etkin ve adil iş dağılımı şeklinde olduğu görülmektedir. İzleyen faktörler, esnek çalışma imkanları, etkin performans değerleme sisteminin kurulması, kararlara katılım imkanının sağlanması, çalışanlar arasında ayrımcılık yapılmaması ve takım çalışmalarına yer verilmesi şeklinde sıralanmıştır. Sonrasında yer alan beklentiler ise düşüncelere saygı duyulması, özerklik, ödüllendirme sisteminin kurulması, işletmenin kurumsallaşma çalışmaları yapması, yöneticilik becerilerine sahip kişilerin ilgili pozisyonlarda yer alması, yetki ve sorumluluk denkliği, hedeflere ulaşmada daha az baskı yapılması ve sosyal etkinlikler düzenlenmesi şeklindedir.

Katılımcıların beklentilerine ilişkin kendi ifadelerinden bazıları aşağıda yer almaktadır.

"Her çalışanda muhakkak maaş beklentisi vardır. Biz insanların doyumsuz olduğu konu da elbette ki paradır. Şirketin maaş skalası daha yüksek olabilir." (Y8)

"Para odaklı değil, insan odakl bir politika benimsemesi ve çalı̧̧anına daha çok değer veren bir kuruma dönüşmesi tek beklentim." (Y3)

"Kendimi daha fazla geliştirebilmek için eğitim firsatı bekliyorum." (Y14) 
Tablo 7. Y Kuşağının İşletmeden Beklentileri

\begin{tabular}{|l|c|c|}
\hline Tema & $\mathbf{f}$ & $\mathbf{\%}$ \\
\hline Ücret artışı & 8 & 13,3 \\
\hline Kariyer planlama uygulamalarına ve terfi imkanlarına yer verilmesi & 6 & 10,0 \\
\hline Çalışana değer verilmesi & 6 & 10,0 \\
\hline Eğitim ve geliştirme fırsatlarının sağlanması & 5 & 8,3 \\
\hline Prim, yan haklar ve sosyal yardım sağlanması & 5 & 8,3 \\
\hline Fiziki çalışma koşullarının iyileştirilmesi & 3 & 5,0 \\
\hline Etkin kişilerarası ilişki ve iletişim ortamının yaratılması & 3 & 5,0 \\
\hline Yönetimin, çalışanlara amaca uygun, gerçekçi hedefler belirlemesi & 3 & 5,0 \\
\hline Etkin ve adil iş dağılımı & 3 & 5,0 \\
\hline Esnek çalışma imkanlarının sağlanması & 2 & 3,3 \\
\hline Etkin performans değerleme sisteminin kurulması & 2 & 3,3 \\
\hline Çalışanların kararlara katılımının sağlanması & 2 & 3,3 \\
\hline Çalışanlar arasında ayrımcılık yapılmaması & 2 & 3,3 \\
\hline Takım çalışmalarına yer verilmesi & 2 & 3,3 \\
\hline Düşüncelere saygı duyulması & 2 & 1,7 \\
\hline Özerklik & 1 & 1,7 \\
\hline Ödüllendirme sisteminin oluşturulması & 1 & 1,7 \\
\hline İşletmenin kurumsallaşma çalışmaları yapması & 1 & 1,7 \\
\hline Yöneticilik becerilerine sahip kişilerin ilgili pozisyonlarda yer alması & 1 & 1,7 \\
\hline Yetki ve sorumluluk denkliği & 1 & 1,7 \\
\hline Hedeflere ulaşmada daha az baskı yapılması & 1 & 1,7 \\
\hline Sosyal etkinlikler yapılması & 1 & 1,7 \\
\hline Toplam & 1 & $\mathbf{1 0 0}$ \\
\hline
\end{tabular}

Tablo 8, X ve Y Kuşağı katılımcılarının öncelikli cevaplarında benzerlikleri göstermektedir. Her iki kuşak da yetersiz ücreti, motivasyonu azaltan öncelikli bir faktör olarak belirtmektedir. Çalışma ortamının güler yüz, anlayış, uyum, huzur gibi psikolojik yönleri, her iki kuşak tarafından motivasyonu arttıran öncelikli bir husus olarak gösterilmiştir. Ücret artışı, cazip yan haklar gibi faktörler ise her iki kuşağın işletmelerinden öncelikli ortak beklentisidir.

Tablo 8. X ve Y Kuşağının Öncelikli Cevaplarında Benzerlikler

\begin{tabular}{|c|c|c|c|c|c|}
\hline \multicolumn{2}{|c|}{ Motivasyonu Azaltan Faktörler } & \multicolumn{2}{|c|}{ Motivasyonu Arttıran Faktörler } & \multicolumn{2}{|c|}{ İşletmeden Beklentiler } \\
\hline X Kuşağ1 & Y Kuşağ1 & X Kuşağ1 & Y Kuşağ1 & X Kuşağı & Y Kuşağ1 \\
\hline $\begin{array}{l}\text { *Zamanında } \\
\text { ödenmeyen ve } \\
\text { yetersiz ücret }\end{array}$ & ${ }^{*}$ Yetersiz ücret & $\begin{array}{l}\text { *Anlayışlı, güler } \\
\text { yüzlü ve } \\
\text { uyumlu çalışma } \\
\text { arkadaşları }\end{array}$ & $\begin{array}{l}\text { *Samimi ve } \\
\text { huzurlu çalışma } \\
\text { ortamı } \\
\text { *Güler yüzlü, } \\
\text { yardımsever, } \\
\text { anlayışlı } \\
\text { yöneticiler }\end{array}$ & $\begin{array}{l}\text { *Ücret artışı } \\
\text { *Cazip yan } \\
\text { haklar } \\
\text { sunulması }\end{array}$ & $\begin{array}{l}\text { *Ücret artışı } \\
\text { *Prim, yan } \\
\text { haklar ve } \\
\text { sosyal yardım } \\
\text { sağlanması }\end{array}$ \\
\hline
\end{tabular}

\section{Sonuç ve Tartışma}

Dünya, özellikle son yüzyılda büyük bir dönüşüme sahne olmaktadır. Bilgi ve iletişim teknolojilerinin gelişmeye hızla devam ettiği, küreselleşme ile rekabetin şiddetini arttırdığı, insan haklarının yükselişe geçtiği 21. yüzyıl, çalışma ortamlarını da değiştirmektedir. Değişime ayak uydurarak sürdürülebilir rekabet avantajı ve yaşam gücüne sahip olmak isteyen örgütlerin bu isteklerini gerçekleştirebilmesinin bir yolu da işgücü çeşitliliğinin giderek arttı̆̆ı, birbirinden farklı özelliklere sahip çalışanların oluşturduğu "çok kuşaklı" bir çalışma ortamını daha iyi anlamaktan geçmektedir. Çalışan motivasyonunu sağlamak hiçbir dönemde kolay 
olmamıştır. Ancak, neredeyse dört farklı kuşağın bir arada çalıştığı günümüz örgütlerinde motivasyon, daha da önemli ve zorlu bir konu haline gelmiştir. Özellikle ülkemiz nüfusunun önemli bir kısmını oluşturan ve çalışma hayatında aktif görev alan $X$ ve $Y$ Kuşağının ihtiyaç, istek ve beklentilerini anlamak ve karşılamak büyük önem taşımaktadır.

Bu bağlamda, X ve Y Kuşağı çalışanların motivasyonunu etkileyen faktörleri tespit etme amacını taşıyan çalışmanın, bu kuşaklara ilişkin farkındalıkta literatüre ve uygulamacılara katkı sunacak sonuçlar ortaya koyduğu düşünülmektedir.

Araştırmanın sonuçları, X Kuşağı çalışanların motivasyonunu azaltan dikkate değer pek çok unsur ortaya koymakla birlikte, zamanında ödenmeyen ve yetersiz ücretin en önemli husus olduğunu göstermektedir. Sorumluluklarını yerine getirmeyen çalışanlar ile belirsiz görev tanımları, sırasıyla belirtilen diğer önemli iki faktördür. X Kuşağı tarafından öncelikli belirtilen bu faktörler, çalışanların ekonomik kaygıları ile birlikte sorumluluğa verdikleri önemi ve üstlendikleri görev içeriğine ilişkin netlik ihtiyacını vurgulamaktadır. Bununla birlikte, çalışma arkadaşları ile uyumsuzluk ve kurum içi dedikodudan rahatsızlığını dile getiren çalışanlar, huzurlu bir çalışma ortamı aramaktadır. Bu kuşak çalışanların, motivasyonu arttıran ilk faktör olarak gösterdikleri anlayışlı, güler yüzlü ve uyumlu çalı̧̧ma arkadaşları, bu ihtiyacı destekleyen bir bulgudur. Motivasyonu arttıran sırasıyla diğer iki faktör, saygı ve hoşgörü gösterilmesi ile ücret artışıdır. İşte başarı, özerklik, ödüllendirme, etkin iletişim ve geribildirim hususlarının da X Kuşağının motivasyonunda önemli faktörlerden olduğu görülmektedir. Ücret artışı ve cazip yan haklar, X Kuşağının işletmelerinden en öncelikli beklentileri olup, bu sonuçlar ekonomik kaynakların bu kuşak çalışanlar için önemini ortaya koymaktadır. Ayrıca, ödüllendirme sisteminin kurulması ve değişen koşullara uygun çalışma araçgereçlerinin sağlanması, çalışanların öncelikli olarak belirttikleri diğer iki husustur.

Araştırma, Y Kuşağının motivasyonunu etkileyen birçok faktör ortaya koymakla beraber, Y Kuşağı için motivasyonu azaltan en önemli faktör, gereksiz, uzun ve yavaş bürokratik süreçlerdir. Fiziki çalışma koşullarının yetersizliği ikinci sırada yer alırken, yetersiz ücret, kariyer planlama ve geliştirme uygulamalarının eksikliği, iş yükünün fazla ve dengesiz dağıtımı, katı hiyerarşik yapı, iletişim sorunları ve adam kayırmacılık, Y Kuşağı çalışanlar tarafından gösterilen diğer önemli hususlardır. Y Kuşağı tarafından en öncelikli belirtilen bu faktörler, bürokrasi ve hiyerarşiye mesafeli duruşlarını gösterdiği gibi, esneklik ihtiyacı ve sabırsızlık özelliklerini de vurgulamaktadır. İletişim ve adalet konularında duyarlı bu çalışanlar, mesleki gelişime verdikleri önem kadar, ücreti de önemsemektedir. Y Kuşağı katılımcılar, motivasyonu arttıran ilk faktör olarak samimi ve huzurlu çalışma ortamını belirtmektedir. Esnek çalışma ile kararlara katılım imkanları, diğer önemli iki faktördür. Başarıların takdir edilmesi ve ödüllendirilmesi, etkin iletişim ve geribildirim, güler yüzlü, yardımsever, anlayışlı yöneticiler bu kuşak çalışanlar tarafından gösterilen diğer önemli hususlardır. Motivasyonu öncelikli azaltan faktörlerde görülen bürokrasi ve hiyerarşiye düşük tolerans, motivasyonu arttıran öncelikli faktörlerde samimiyet, esneklik, katılım bulgularını destekler niteliktedir. Çalışanların işletmelerinden en önemli beklentisi, ücret artışıdır. Kariyer planlama uygulamaları ve terfi imkanlarına yer verilmesi ile kendilerine değer verilmesi, diğer önemli iki beklentidir. Ayrıca, eğitim ve geliştirme fırsatları ile prim, yan haklar ve sosyal yardım sağlanması, belirtilen diğer öncelikli hususlardır. Öte yandan, ücreti motivasyonu azaltan öncelikli bir faktör olarak gösterirken, arttıran öncelikli bir faktör olarak görmeyen, ancak ilk sıradaki beklentisine koyan Y Kuşağı katılımcılarının, bu faktörü yokluğu tatminsizliğe yol açan, ancak varlığı motivasyon artışı sağlamayan, bir başka deyişle, gerekli ancak yeterli olmayan bir "hijyen faktör" olarak değerlendirdiği de söylenebilir. Benzer bir durum, fiziki çalışma koşulları için geçerlidir. Motivasyonu azaltan ikinci faktör olarak gösterilen bu husus, katılımcılar tarafından motivasyonu arttıran bir faktör olarak gösterilmemiş olup, beklentilerde öncelikli faktörler arasında yer almaktadır. Dolayısıyla, fiziki çalışma koşullarının da bir "hijyen faktör" olarak görüldüğünü söylemek mümkündür.

Araştırmanın bulguları birlikte değerlendirildiğinde, ekonomik faktörlerin $X$ Kuşağı çalışanların motivasyonunda çok büyük öneme sahip olduğu görülmektedir. Çünkü bu husus, katılımcıların motivasyonu azaltan ve arttıran faktörler ile işletmeden beklentilere ilişkin verdikleri öncelikli ortak cevaptır. Araştırma ortaya koyduğu bu sonuç ile Aksu ve Doğan (2020: 2040-2060) ve Çökerdenoğlu (2019: 1-112) tarafından yapılan araştırmanın bulguları ile benzerlik göstermektedir. Ayrıca, çalışma ortamının anlayış, uyum, cana yakınlık, hoşgörü, saygı gibi psikolojik yönlerinin bu kuşak çalışanların motivasyonunda önemli bir diğer boyut olduğu bulgusu ile araştırma, Baran (2018: 1-98) ve Kicheva (2017: 103-121) tarafından gerçekleştirilen 
çalışmaların sonuçları ile paralellik göstermektedir. Bununla birlikte, çalışmada işte başarı, özerklik ve sorumluluğa yaptıkları vurgu ile $X$ Kuşağı çalışanlar, yerli ve yabancı literatürde kendileri için yapılmış bu tanımlamalara da uymaktadır. Öte yandan, literatürde $X$ Kuşağı için önemli bir husus olarak belirtilen işyaşam dengesi, bu çalışmada yalnızca "uzun ve yorucu çalışma saatleri" görüşü ile sınırlı kalmış; katılımcılar tarafından özellikle vurgulanan bir cevap olmamıştır. Araştırma, ekonomik araçlar ile birlikte kariyer gelişiminin Y Kuşağının motivasyonunu etkileyen önemli hususlar olduğunu ortaya koymaktadır. Araştırma bu sonuçları ile Kuran (2019b: 42-61) ve Aksu ve Doğan (2020: 2040-2060) tarafından yapılan çalışmalar ile benzerlik göstermektedir. Bununla birlikte, Y Kuşağı değer gördükleri, samimi, esnek ve rahat bir ortamda çalışmayı istemektedir. Araştırma bu bulguları ile Keleş (2011: 129-139), Can (2018: 1-235), Baran (2018: 1-98) ve Çökerdenoğlu (2019: 1-112) tarafından yapılan araştırmaların sonuçları ile paralellik göstermektedir. Ayrıca, araştırmanın öncelikli bu sonuçları, Y Kuşağı katılımcılarının, yerli ve yabancı literatürde kendileri için yapılmış tanımlamalara uyduğunu göstermektedir. Bununla birlikte, çalışmada $X$ ve $Y$ Kuşağ 1 katılımcılarının öncelikli cevaplarında bazı benzerlikler dikkat çekmektedir. Her iki kuşak da çalışma ortamının güler yüz, anlayış, uyum, huzur gibi psikolojik yönlerini, motivasyonu arttıran öncelikli bir faktör olarak göstermiştir. Ayrıca, ekonomik faktörler, her iki kuşağın motivasyonunu azaltan ortak husus olduğu gibi, aynı zamanda işletmelerinden ortak beklentisidir. Bu bulgu, Raganowicz-Gargasz (2014: 1-109) ve Can (2018: 1-235) tarafından yapılan araştırmaların sonuçları ile benzerlik göstermektedir.

Yukarıdaki değerlendirmeler ışığında, $X$ ve $Y$ Kuşağının motivasyonunu etkileyen öncelikli faktörlerde farklılıklar olduğu gibi, bu kuşakların bazı hususlarda birleştiklerini de söylemek mümkündür. Bu bağlamda, örgütler, günümüz çok kuşaklı çalışma ortamının dinamiklerini anlamaya ilişkin daha yüksek düzeyde çaba göstermelidir. Örgütlerin kuşaklar arasındaki farklılıkları ve benzerlikleri dikkate alarak oluşturacağı çalışma ortamı, bu kuşakların motivasyonunu arttıracağı gibi, yeteneklerin elde tutulması ve çalışan bağlılığının sağlanması ile birlikte örgütün rekabet gücü, performansı ve sürdürülebilirliğine katkı sunacaktır.

Araştırma, kullandığı metodoloji itibariyle genelleme yapma amacı taşımamaktadır. Gelecekteki araştırmaların, aynı kuşaklar ile veya Z Kuşağını da kapsayan örneklemlerde genelleme yapılabilecek nicel yöntemler ile yapılması veya nicel ve nitel yöntemlerin birlikte kullanıldığı çalışmaların tasarlanması, özellikle yerli literatüre önemli katkı sağlayacağı gibi, uygulamacılara, bu kuşakların istek ve beklentilerine uygun bir çalışma ortamı oluşturmalarında yol gösterici olacaktır.

\section{Kaynakça}

Adair, J. (2013). Etkili Motivasyon, Uyan, S. (Çev.), İstanbul: Babıali Kültür Yayıncılığı.

Aksu, B. Ç. ve Doğan, A. (2020). Kuşaklar Açısından Motivasyon Araçlarının ve Kariyer Çapalarının Karşılaştırılması, İşletme Araştırmaları Dergisi, 12(2), 2040-2060.

Baran, A. (2018). X ve Y Kuşağı Mensubu Satış Danışmanlarının Motivasyon Faktörleri Arasındaki Farklılıklar; Otomotiv Sektöründe Bir Araştırma, Yüksek Lisans Tezi, Maltepe Üniversitesi, Sosyal Bilimler Enstitüsü.

Barreto, M. A. M., Vasconcelos, S. S. and dos Santos, E. F. (2018). Motivation and work: A survey of the motivational aspects in industries, Kantola, J. I. et al. (Eds.), Advances in Human Factors, Business Management and Leadership, Advances in Intelligent Systems and Computing 594, Springer International Publishing, 319-328.

Bayramoğlu, G. (2018). X ve Y Kuşağının Liderlik Davranışı Açısından Karşılaştırılması, Ege Akademik Bakı̧̧, $18(1), 15-29$.

Can, M. (2018). Motivasyon Araçlarının Kuşaklar ve Örgüt Kültürü Bağlamında Karşılaştırılmalı Analizi: Konaklama İşletmelerinde Bir Uygulama, Doktora Tezi, Gazi Üniversitesi, Sosyal Bilimler Enstitüsü.

Capital. (2010). Motivasyon 3.0 Dönemi Başlıyor, Sayı: 3, 190-193.

Çetin Aydın, G. ve Başol, O. (2014). X ve Y Kuşağı: Çalışmanın anlamında bir değişme var mı?, Electronic Journal of Vocational Colleges, 1-15. 
Çökerdenoğlu, H. (2019). Öğretmenlerin Kuşak Bağlamında Değişen Motivasyon Araçları: X ve Y Kuşağı Öğretmenleri Aynı Araçlarla mı Motive Olur?, Yüksek Lisans Tezi, Kocaeli Üniversitesi, Sosyal Bilimler Enstitüsü.

Deloitte. (2017). The 2017 Deloitte Millennial Survey Apprehensive millennials: seeking stability and opportunities in an uncertain world, https://www2.deloitte.com/content/dam/Deloitte/global/Documents/About-Deloitte/gx-deloittemillennial-survey-2017-executive-summary.pdf, 1-33, Erişim Tarihi: 04/10/2019.

Ekşili, N. ve Antalyalı, Ö. L. (2017). Türkiye'de Y Kuşağı Özelliklerini Belirlemeye Yönelik Bir Çalışma: Okul Yöneticileri Üzerine Bir Araştırma, Humanities Sciences, 12(3), 90-111.

Eriş, E. D., Özer, P. S., Özmen, Ö. N. T., Çakır, Ö. ve Tozkoparan, G. (2013). Generation “Y” in Turkish Context: Multiple Foci Research, International Journal of Business and Management Studies, 5(1), 150-161.

Fatimah, H., Dharmawan, A. H., Sunarti, E. and Affandi, M. J. (2015). The influence of communication and motivation factors on employee engagement in the generation $X$ and $Y$, International Journal of Information Technology and Business Management, 38(1), 22-30.

Gross, T. S. (2017). Milenyum Kuşă̆ının Kuralları, Tokyay, M. (Çev.), İstanbul: İKÜ Yayınevi.

Hays. (2013a). Gen Y and the world of work, https://social.hays.com/wpcontent/uploads/2013/10/Hays Report V4 02122013 online.pdf, 1-24, Erişim Tarihi: 01/10/2019.

Hays. (2013b). Gen Y and the world of work, https://social.hays.com/wpcontent/uploads/2014/01/HAYS REPORT JAPAN 02122013 online.pdf, 1-28, Erişim Tarihi: 01/10/2019.

Hays. (2014). Gen Y and the world of work https://social.hays.com/wpcontent/uploads/2014/09/HAYS REPORT DE VERSION online.pdf, 1-28, Erişim Tarihi: 01/10/2019.

Herzberg, F. (2017). Bir Kere Daha: Çalışanları Nasıl Motive Edersiniz?, İnan, M. (Çev.), HBR's 10 Must Reads - İnsan Yönetimi, Optimist Kitap, 43-68.

Jiří, B. (2016). The Employees of Baby Boomers Generation, Generation X, Generation Y and Generation Z in Selected Czech Corporations as Conceivers of Development and Competitiveness in their Corporation, Journal of Competitiveness, 8(4), 105-123.

Keleş, H. N. (2011). Y Kuşağı Çalışanlarının Motivasyon Profillerinin Belirlenmesine Yönelik Bir Araştırma, Organizasyon ve Yönetim Bilimleri Dergisi, 3(2), 129-139.

Kian, T. S., Yusoff, W. F. W. and Rajah, S. (2013). Relationship between motivations and citizenship performance among generation $\mathrm{X}$ and generation $\mathrm{Y}$, International Journal of Academic Research in Business and Social Sciences, 3(11), 53-68.

Kicheva, T. (2017). Management of Employees from Different Generations - Challenge for Bulgarian Managers and HR Professionals, Economic Alternatives, 1, 103-121.

KONDA. (2011). Türkiye Gençliği Araştırması, http://konda.com.tr/wpcontent/uploads/2017/02/2011 05 KONDA Turkiye Gencligi Arastirmasi.pdf, 1-28, Erişim Tarihi: $02 / 10 / 2019$.

Kubátová, J. and Kukelková, A. (2014). Cultural differences in the motivation of Generation Y knowledge workers, Human Affairs 24, 511-523.

Kuran, E. (2018). Türkiye'nin Y Kuşağı Şirketlere Ne Söylüyor?, Harvard Business Review Türkiye, Y1l: 7, Sayı: 9, 42-63.

Kuran, E. (2019a). Telgraftan Tablete, İstanbul: Destek Yayınları.

Kuran, E. (2019b). Türkiye'nin Gençleri İş Yaşamından Ne Bekliyor? Şirketleri Nasıl Görüyor?, Harvard Business Review Türkiye, Yı1: 8, Sayı: 9, 42-61. 
E. Y1ld1z 13/1 (2021) 216-234

Leavitt, R. (2014). Generational Differences in Work Motivation of Healthcare Workers, Doctoral Dissertation, University of Nebraska-Lincoln.

Loveland, E. (2017). Instant Generation, Journal of College Admission, 235, 34-38.

Mannheim, K. (2018). Bilgi Sosyolojisi, Yalçınkaya, M. (Çev.), İstanbul: Pinhan Yayıncılık.

Ng, E. S., Schweitzer, L. and Lyons, S. T. (2010). New Generation, Great Expectations: A Field Study of the Millennial Generation, Journal of Business and Psychology, 25(2), 281-292.

Palfrey, J. ve Gasser, U. (2017). Doğuştan Dijital: Dijital Yerlilerin İlk Kuşağını Anlamak, Aydın, N. (Çev.), İstanbul: İKÜ Yayınevi.

Patton, M. Q. (2014). Nitel Araştırma ve Değerlendirme Yöntemleri, Bütün, M. ve Demir, S. B. (Çev. Edt.), Ankara: Pegem Akademi Yayınları.

Raganowicz-Gargasz, K. (2014). Comparative empirical analysis of motivational differences of various generational cohorts in the Irish workplace, Master Thesis, Dublin Business School.

Robbins, S. P. and Judge, T. A. (2013). Organizational Behavior, 15th Edition, Pearson.

Schermerhorn, J. R. (2012). Management, 11th Edition, John Wiley \& Sons, Inc.

Sosyal Demokrasi Vakfı. (2020). Türkiye'nin Gençliği Araştırması Raporu, http://sodev.org.tr/wpcontent/uploads/2020/05/arastirma.pdf, 1-12, Erişim Tarihi: 12/06/2020.

Sökmen, A. (2013). Örgütsel Davranış, Ankara: Detay Yayıncılık.

Steers, R. M., Mowday, R. T. and Shapiro, D. L. (2004). The Future of Work Motivation Theory, Academy of Management Review, 29(3), 379-387.

Süral Özer, P. (2016). Bilgi Çağında Yeni Bir Kuşak Farklı Bir Sınıf: Y Kuşağı Bilgi İşçileri ve Kariyerlerinin Yönetimi, Şimşek, M. Ş., Çelik, A. ve Akatay, A. (Edt.), Insan Kaynakları Yönetimi ve Kariyer Uygulamaları, 343-366.

Taş, H. Y. ve Kaçar, S. (2019). X, Y ve Z Kuşağı Çalışanlarının Yönetim Tarzları ve Bir İşletme Örneği, OPUS Uluslararası Toplum Araştırmaları Dergisi, 11(18), 643-675.

TÜIKK. Yaş Grubu ve Cinsiyete Göre Nüfus, https://www.tuik.gov.tr/, Erişim Tarihi: 24/07/2020.

Yıldırım, A. ve Şimşek, H. (2018). Sosyal Bilimlerde Nitel Araştırma Yöntemleri, Ankara: Seçkin Yayıncılık.

Yusoff, W. F. W. and Kian, T. S. (2013). Generation Differences in Work Motivation: From Developing Country Perspective, International Journal of Economy, Management and Social Sciences, 2(4), 97-103.

Zemke, R., Raines, C. and Filipczak, B. (2000). Generations at Work -Managing the Clash of Veterans, Boomers, Xers and Nexters in Your Workplace-, http://www.cognitionnet.com/member/resources/Summaries/Personnel HR/Generations at Work.p df 1-8, Erişim Tarihi: 28/08/2019. 